\title{
Fields with no recent legume cultivation have sufficient nitrogen-fixing rhizobia for crops of faba bean (Vicia faba $\mathrm{L}$.)
}

\author{
Marta Maluk (D) Francesc Ferrando-Molina (D) Laura Lopez del Egido • Adrian Langarica-Fuentes • \\ Genet Gebre Yohannes • Mark W. Young (D) Peter Martin (D) Richard Gantlett • Greg Kenicer • \\ Cathy Hawes • Graham S. Begg • Richard S. Quilliam (D) Geoffrey R. Squire (D) J. Peter W. Young (D) \\ Pietro P. M. Iannetta (D) Euan K. James $(1)$
}

Received: 23 March 2021 / Accepted: 24 November 2021 / Published online: 20 January 2022

(C) The Author(s) 2021

\begin{abstract}
Purpose (1) To assess the biological N fixation (BNF) potential of varieties of faba bean (Vicia faba L.) cropped with or without compost in an experimental field-scale rotation with no recent history of legumes, (2) to enumerate soil populations of Rhizobium leguminosarum sv. viciae $(R l v)$, and to genetically characterize the nodulating $R l v$ strains, (3) compare BNF with other sites in Britain.
\end{abstract}

Responsible Editor: Katharina Pawlowski

Supplementary Information The online version contains supplementary material available at https://doi. org/10.1007/s11104-021-05246-8.

M. Maluk · L. Lopez del Egido · M. W. Young ·

C. Hawes · G. S. Begg · G. R. Squire · P. P. M. Iannetta

E. K. James $(\triangle)$

Ecological Sciences, The James Hutton Institute,

Invergowrie, DD2 5DA Dundee, UK

e-mail: Euan.James@hutton.ac.uk

F. Ferrando-Molina · R. S. Quilliam

Biological and Environmental Sciences, University

of Stirling, FK9 4LA Stirling, UK

Present Address:

L. Lopez del Egido

Seed Crops \& Technology Flowers, Syngenta Flowers B.V,

Westeinde 62, 1601 BK Enkhuizen, The Netherlands

A. Langarica-Fuentes

Applied Geosciences, Universität Tübingen,

Schnarrenbergstr. 94-96, 72076 Tübingen, Germany
Methods BNF was evaluated from 2012 to 2015 using ${ }^{15} \mathrm{~N}$ natural abundance. Treatments were either PK fertilizer or compost. Soil rhizobial populations were determined using qPCR, the symbiotic rhizobia genotyped (16 S rRNA, nodA and nodD genes), and their BNF capacity assessed ex situ. The reliance of legumes on BNF at other British sites was estimated in a single season, and their nodulating symbionts examined.

Results Faba bean obtained most of its $\mathrm{N}$ through BNF (>80\%) regardless of variety or year. $\mathrm{N}$-accumulation by cvs Babylon and Boxer increased with compost treatment in 2014/2015. Rhizobial populations were c. $10^{5}-10^{6} \mathrm{Rlv}$ cells $\mathrm{g}^{-1}$ soil regardless of field or treatment. $157 R l v$ microsymbionts grouped

\section{G. G. Yohannes}

Department of Microbial, Cellular and Molecular Biology, Faculty of Life Science, Addis Ababa University, P.O. Box 1176, Addis Ababa, Ethiopia

P. Martin

University of the Highlands and Islands, Orkney College UHI, Kirkwall KW15 1LX, UK

R. Gantlett

Soil Research Centre, School of Agriculture, Policy and Development, University of Reading, Whiteknights, Reading RG6 6AR, UK

G. Kenicer

Royal Botanical Garden Edinburgh, 20A Inverleith Row, Edinburgh EH3 5LR, UK 
into two large nodAD clades; one mainly from $V$. $f a b a$, and the other from various legumes. All isolates nodulated, and some performed better than commercial inoculant strains.

Conclusions Faba bean can provide most of its nitrogen through $\mathrm{BNF}$ and leave economically valuable residual $\mathrm{N}$ for subsequent crops. Recent legume cropping in northern Europe is not essential for effective nodulation: rhizobia may persist in a range of farmland locations. Nevertheless, there is the potential to apply elite rhizobial strains as inoculants in some soils.

Keywords Vicia faba L. · Green waste compost . ${ }^{15} \mathrm{~N}$ natural abundance $\cdot$ Nitrogen fixation .

Rhizobium $\cdot \mathrm{qPCR} \cdot \operatorname{nodD}$

$\begin{array}{ll}\text { Abbreviations } \\ \text { Rlv } & \text { Rhizobium leguminosarum sv. viciae } \\ \text { CSC } & \text { Centre for Sustainable Cropping } \\ \text { qPCR } & \text { quantitative Polymerase Chain Reaction } \\ \text { BNF } & \text { Biological Nitrogen Fixation } \\ \text { GHG } & \text { Greenhouse gases } \\ \text { \%Ndfa } & \text { Proportion of Nitrogen derived from air } \\ \text { bp } & \text { base pair } \\ \text { REML } & \text { Restricted Maximum Likelihood } \\ \text { SDW } & \text { Sterile Distilled Water }\end{array}$

\section{Introduction}

Nodulated legumes are the largest contributors of biologically fixed nitrogen $(\mathrm{N})$ to both natural terrestrial and agricultural environments and are a key component of sustainable agriculture (Cleveland et al. 1999; Jensen et al. 2012; Peoples et al. 2009; Udvardi et al. 2021; Unkovich et al. 2008). The root nodulating symbioses that they form with a diverse range of soil bacteria, collectively termed "rhizobia" (De Meyer et al. 2011; Gyaneshwar et al. 2011; Peix et al. 2015), are capable of fixing more than $200 \mathrm{~kg}$ $\mathrm{N}$ ha ${ }^{-1} \mathrm{yr}^{-1}$ in agricultural systems in both tropical (Alves et al. 2003) and temperate regions (Carlsson and Huss-Danell 2003; Iannetta et al. 2016; Jensen et al. 2010). These systems include legumes grown for their high protein grains (for both human and

J. P. W. Young

Department of Biology, University of York,

York YO10 5DD, UK animal consumption), as animal forage and fodder, and as "green manures", intercrops and understories.

If appropriately managed, legume crops can achieve high yields without applications of mineral $\mathrm{N}$-containing fertiliser; in addition, they have the potential to contribute substantial amounts of fixed $\mathrm{N}$ to the succeeding non-legume crop (e.g. in rotations or crop sequences) or directly when used as green manures, intercrops or understoreys. While legumes are increasingly being used in tropical countries, e.g. soybean in Brazil (Alves et al. 2003), their use in northern European agriculture has greatly declined over the last 150 years (Squire et al. 2019). Since the mid-1900s, northern European crop systems have gained most of their $\mathrm{N}$ from synthetic fertilisers manufactured using the Haber-Bosch process, which has subsequently replaced the role of $\mathrm{N}$-fixing legumes in cereal rotations and pastures. However, it is also now apparent that overuse of industrially-produced $\mathrm{N}$-containing fertilisers can lead to eutrophication of rivers and the pollution of groundwater, and following denitrification can contribute substantial amounts of greenhouse gases (GHG) such as $\mathrm{N}_{2} \mathrm{O}$ (Jensen et al. 2012). Given the likelihood of further statutory curbs on the use of $\mathrm{N}$-fertilisers, and growing acceptance that locally-grown pulses deliver improvements to human and animal nutrition with reduced economic and environmental costs compared to the importation of legume grain (e.g. of soybean from the Americas), the demand for $\mathrm{N}$-fixing legumes in northern European cropping systems is expected to increase (Iannetta et al. 2016).

The most economically important grain legumes (pulses) in the UK and northern Europe in general are pea (Pisum sativum L.) and faba bean (Vicia faba L.), which are cropped for their high protein grains. Faba bean is capable of high biological $\mathrm{N}$ fixation (BNF) in many parts of the world, including Australia and Canada (Denton et al. 2013; Hossain et al. 2016; Unkovich et al. 2010; Van Zwieten et al. 2015), but also in Europe, where ${ }^{15} \mathrm{~N}$-based field studies have indicated that it can fix between 73 and $335 \mathrm{~kg}$ shoot $\mathrm{N} \mathrm{ha}^{-1} \mathrm{yr}^{-1}$ (Giambalvo et al. 2012; Jensen et al. 2010; López-Bellido et al. 2006). However, there have been no studies to quantify BNF in the cooler, wetter climates of the British Isles since Sprent et al. (1977) estimated very large inputs of fixed $\mathrm{N}\left(600 \mathrm{~kg} \mathrm{ha}^{-1} \mathrm{yr}^{-1}\right)$ from faba bean grown in East Scotland (UK) using the acetylene reduction 
assay. Faba bean varieties, farmers' practices and management have changed considerably over the last 40 years, and so these early BNF estimates may not reflect the position in commercial agriculture today. Even less is known about BNF by pea in the British Isles, although it is known to fix large amounts of $\mathrm{N}$ (albeit less than faba bean) in other parts of the world (HauggaardNielsen et al. 2010; Hossain et al. 2016; Jensen 1986; 1987; Unkovich et al. 2010; Unkovich et al. 2008).

Two critical factors need to be resolved before any programme for legume expansion can be put in place. First, in general, legumes will only nodulate and fix $\mathrm{N}$ if they need to, i.e. if the soil $\mathrm{N}$ status is sufficiently low (Jensen et al. 2010; Peoples et al. 1991; Unkovich et al. 2008). However, northern European soils are usually already enriched in $\mathrm{N}$ because of the intensive use of fertilisers typical of commercial arable rotations, and so in order to induce legumes to nodulate and fix $\mathrm{N}$, concentrations of soil $\mathrm{N}$ may need to be reduced, for example by the prior use of an N-demanding crop (Jensen et al. 2010; Van Zwieten et al. 2015). Second, suitable bacteria need to be present in the soil. Faba bean, pea and lentil (Lens culinaris Medik.) are all nodulated by the common soil bacterium Rhizobium leguminosarum sv. viciae (Rlv) (Laguerre et al. 2003), which also nodulates several native European legumes in the genera Lathyrus and Vicia (Mutch and Young 2004). Populations of rhizobia are adversely affected by high soil $\mathrm{N}$, but also by the absence of legume host crops over a prolonged period (Jensen et al. 2010). This means that a legume crop may have reduced nodulation and $\mathrm{N}$-fixation capacity (and may even fail altogether) if care is not taken to ensure that an adequately high population of suitable rhizobia is present in the soil. In studies of UK soils, Nutman and Hearne (1979) reported >1000-fold reductions in $R l v$ populations under continual fallow or cereal cropping, and Sorwli and Mytton (1986) suggested that BNF by faba bean might be limited by low rhizobial populations and/or ineffective $R l v$ genotypes. Similarly, in France, Depret et al. (2004) concluded that long-term cropping of cereals, particularly maize (Zea mays L.), resulted in a marked decrease in the diversity of $R l v$. More recently, Walker and Watson (2011) have recommended that pulse crops in the UK are inoculated with $R l v$ as part of a strategy to overcome "yield instability" brought about by reductions in $R l v$ populations as a consequence of the long-term absence of legumes in many soils.

The opportunity to test the overarching hypothesis that the prolonged absence of legume cropping results in reductions in soil Rlv populations, and hence impacts negatively on yields by legume crops that are largely dependent on BNF, arose at the Centre for Sustainable Cropping (CSC). The CSC is a long-term experimental platform close to Dundee, Scotland, with no recent history of legume cropping. Furthermore, it was established with the primary aim of testing whether yields obtained by conventional arable management comprising standard local fertiliser inputs can be maintained or even bettered under a low-input integrated system comprising inputs of green waste compost only (Hawes et al. 2018). Therefore, it also allowed for testing the additional hypothesis that applications of compost can help maintain (and even enhance) soil $R l v$ populations, and hence legume BNF and grain yields.

In this context, there were five aims to the present study:

1. To determine the contribution of BNF to several varieties of faba bean in a four-year field-scale arable rotation in soils amended with or without compost.

2. To estimate populations of $R l v$ in the faba beancropped soils using a qPCR approach based on $16 \mathrm{~S}$ rRNA and nodD primers.

3. Considering the prolonged absence of legume cropping at the site, to determine the potential origins of the $R l v$ strains nodulating the faba bean by comparing them genetically with strains isolated from neighbouring domesticated and wild relatives of faba bean in the genera Vicia, Pisum, Lathyrus and Lens.

4. To assess the plant growth-promoting performance of the rhizobial isolates.

5. To assess the degree to which the N-needs of pea and faba bean crops in other parts of Britain are met by BNF, and to use these crops as additional sources of genetically and functionally diverse $R l v$ genotypes to compare with those isolated from the main study site and its immediate environs. 


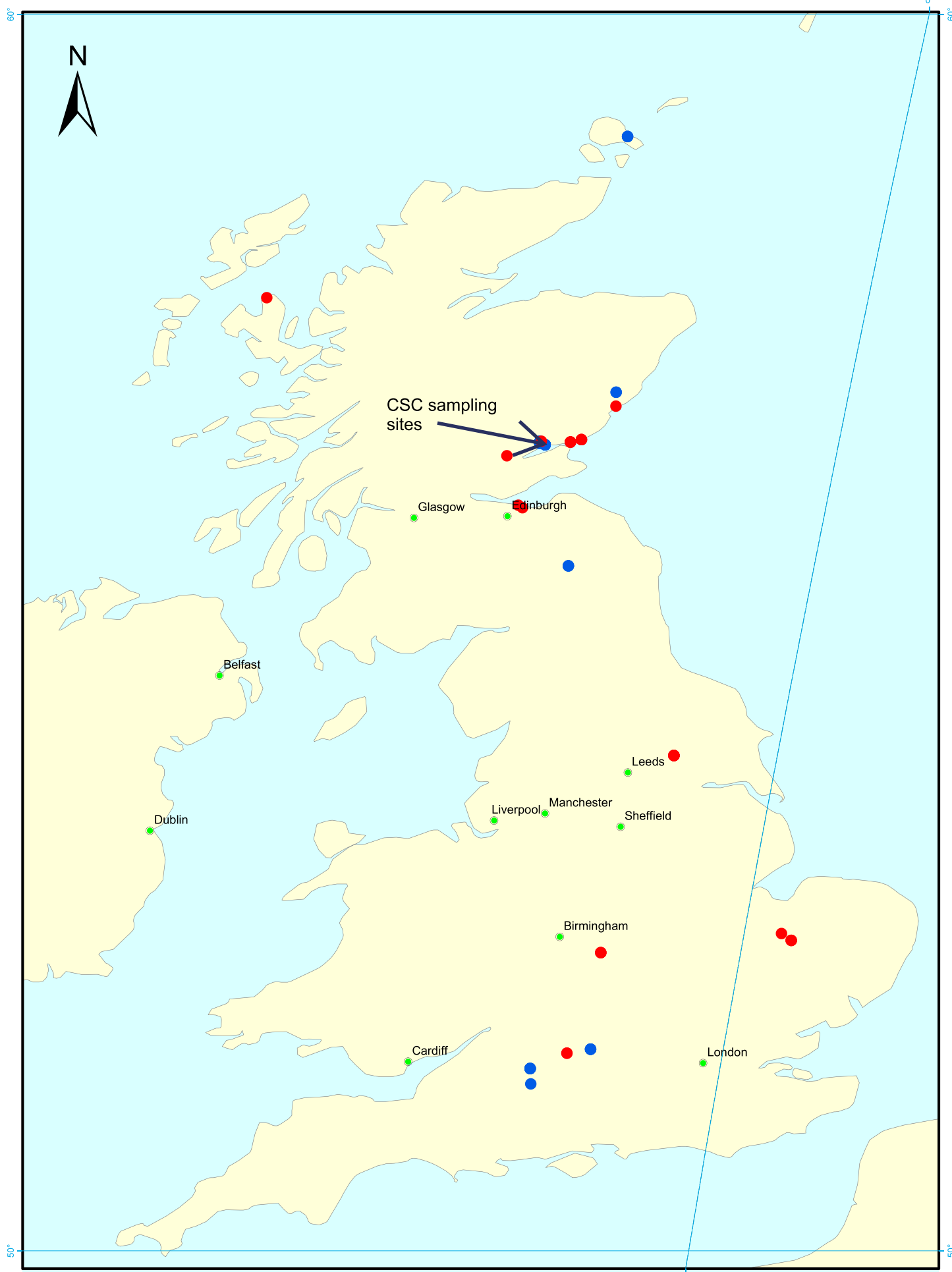

Legend

- Legume nodule sampling sites

$\begin{array}{llll}0 & 30 & 60 & 120 \text { Kilometers }\end{array}$

- BNF measuring and legume nodule sampling sites

$1+1+1+1$ 
4Fig. 1 A map of the British Isles showing the location of the legume nodule sampling sites (red spots) and sites where biological $\mathrm{N}$ fixation (BNF) was also measured (blue spots). Major cities are marked in green. The CSC is indicated by an arrow

\section{Materials and methods}

Experimental design of a 4-year experimental crop sequence at the CSC incorporating faba bean

Faba bean was sampled annually from 2012 to 2015 at the CSC field-scale experimental platform in Balruddery Farm, Dundee, North-East Scotland, UK (56.48 lat, -3.13 long). The location of the CSC is indicated in Fig. 1, along with the other sites where BNF was assessed and/or rhizobia were sampled (Table S1). The fields comprising the CSC were not cropped with legumes for at least 50 years prior to the onset of the experimental rotation in 2011; they provided grass for grazing and/or cattle fodder until the late 1990s, and thereafter were part of an arable rotation mainly comprising winter cereals. The CSC experimental platform is a 42 ha contiguous block of six arable fields based on a six year rotation of the commonly grown crops in the region: potatoes (Solanum tuberosum L.), winter wheat (Triticum aestivum L.), winter barley (Hordeum vulgare L.), winter oilseed rape (Brassica napus L.), spring sown faba bean and spring barley. It was established as a long-term field platform in which conventional arable management is being compared with a low-input, integrated cropping system designed with the goal to maintain yields whilst enhancing biodiversity and minimizing environmental impact. More details about the CSC can be found in Hawes et al. (2018) and Freitag et al. (2018), and at https://csc.hutton.ac.uk. The soil N-status of each field is shown in Table 1 along with the non-legume crop that preceded faba bean. Monthly average temperature and precipitation during the 2012-2015 growing seasons are shown in Fig. S1.

The experimental crop sequence was conducted on four of the six fields comprising the CSC; each 6-7 ha field was divided in half: one half (labelled conventional) was treated with a standard application of fertilizer currently used in east Scotland (i.e. PK, but not $\mathrm{N}$ ), while the other half (labelled integrated) received a reduced level of PK fertilizer, but was also treated with green waste compost containing $1.35 \% \mathrm{~N}$ and
$16.01 \% \mathrm{C}$, which was applied annually before seed sowing at a rate of $35 \mathrm{t} \mathrm{ha}^{-1}$ (Table 1). In each season, four to five varieties of faba bean were sown in $18 \mathrm{~m}$ wide strips in each field half at a sowing density of $210-320 \mathrm{~kg} \mathrm{ha}^{-1}$, depending on variety. Although some of the varieties changed over the four seasons owing to difficulties in obtaining sufficient quantities of seed, two of them (cvs Fuego and Pyramid) were sown in each year from 2012 to 2015.

Calculation of BNF using the ${ }^{15} \mathrm{~N}$ natural abundance technique

Biomass and BNF measurements were undertaken at early to mid-podfill, when grain legume BNF is maximal (i.e. early to mid-podfill; Jensen et al. 2010; Rose et al. 2018; Unkovich et al. 2008), which is normally late July/early August in Scotland. Faba bean plants in $0.5 \mathrm{~m}^{2}$ sampling points, (five points per strip), were harvested and the dry biomass of the entire aerial parts (stems, leaves and pods) was weighed for an estimate of above-ground biomass per hectare (Fretiag et al. 2018; Hawes et al. 2018). A single whole faba bean plant with an intact nodulated root system was sampled from the edge of each sampling point (Freitag et al. 2018; Hawes et al. 2018). Adjacent non-legume dicot weeds or non-legume crop volunteers were sampled as non-N-fixing reference plants for ${ }^{15} \mathrm{~N}$ natural abundance assays (Carlsson and HussDanell 2014) (listed in Table S2); at least one reference plant was sampled from each of the five sampling points, so that each strip was represented by five faba bean plants and five references. These were set aside for $\% \mathrm{~N}$ and ${ }^{15} \mathrm{~N}$ analysis (see next section). The crop was harvested according to standard farm practice in September or October, depending on the weather. The dry weight of grain per $18 \mathrm{~m}$-wide strip was converted to yield in $\mathrm{tha}^{-1}$ (taking into account a standard $15 \%$ moisture content).

The five individual faba bean plants per strip were divided into shoots, roots and nodules, which were dried at $60{ }^{\circ} \mathrm{C}$, weighed and milled to a fine powder. The same was done with the aerial parts of the reference plants. A sub-sample of each plant was analysed using an elemental analyser linked to a mass spectrometer to determine the $\% \mathrm{~N}$ and ${ }^{15} \mathrm{~N}$ contents, respectively. Samples $(0.5 \mathrm{mg})$ were weighed into tin capsules and analysed for the ${ }^{15} \mathrm{~N}$ isotopic composition using an automated nitrogen-carbon elemental 
Table 1 Soil Nitrogen levels and additions in fields used for growing faba bean in the four-year cropping sequence (2012-2015)

\begin{tabular}{|c|c|c|c|c|}
\hline Field & $\begin{array}{l}\text { Plant available } \mathrm{N}^{*} \text { at start of } \\
\text { growing season } \\
\left(\mathrm{kg} \mathrm{ha}{ }^{1}\right)\end{array}$ & $\begin{array}{l}\text { Added plant avail- } \\
\text { able } \mathrm{N} \\
\left(\mathrm{kg} \mathrm{ha}^{1}\right)\end{array}$ & Crop in preceding season & $\begin{array}{l}\text { Added plant available } \\
\mathrm{N} \text { in preceding season } \\
\left(\mathrm{kg} \mathrm{ha}^{1}\right)\end{array}$ \\
\hline \multicolumn{5}{|l|}{ Estate (2012) } \\
\hline Conventional & 51.7 & 0 & Winter barley & 270.0 \\
\hline Integrated & 36.7 & 5.38 & Winter barley & 202.5 \\
\hline \multicolumn{5}{|l|}{ Kennels (2013) } \\
\hline Conventional & 42.7 & 0 & Winter barley & 270.0 \\
\hline Integrated & 44.5 & 5.38 & Winter barley & 202.5 \\
\hline \multicolumn{5}{|c|}{ Middle East (2014) } \\
\hline Conventional & 14.4 & 0 & Winter wheat & 270.0 \\
\hline Integrated & 27.1 & 5.38 & Winter wheat & 202.5 \\
\hline \multicolumn{5}{|c|}{ Den South (2015) } \\
\hline Conventional & 26.4 & 0 & Winter wheat & 270.0 \\
\hline Integrated & 34.3 & 5.38 & Winter wheat & 202.5 \\
\hline
\end{tabular}

$* \mathrm{NO}_{3}{ }^{-}+\mathrm{NH}_{4}{ }^{+}$. Sampling depth was $20 \mathrm{~cm}$, and soil bulk density $=1.3 \mathrm{~g} \mathrm{~cm}^{-3}$

The conventional field halves received a standard (0-20-30) dressing of PK fertiliser (200 $\left.\mathrm{kg} \mathrm{ha}^{1}\right)$, whereas the integrated halves were treated with green waste compost plus (0-20-30) PK fertiliser (150 kg ha $\left.{ }^{1}\right)$. Details are given in the Materials and Methods

analyser (ANCA) coupled to a 20/20 isotope ratio mass spectrometer (both SerCon Ltd., Crewe, UK). The total $\mathrm{N}$ content of the faba bean plants was calculated by multiplying the dry biomass of their shoots by their $\% \mathrm{~N}$. The proportion of faba bean $\mathrm{N}$ derived from atmospheric $\mathrm{N}_{2}$ (\%Ndfa) was calculated by comparing the ${ }^{15} \mathrm{~N}$ natural abundance (expressed as $\delta^{15} \mathrm{~N}$ or parts per thousand [\%o] relative to the ${ }^{15} \mathrm{~N}$ composition of atmospheric $\mathrm{N}_{2}$ ) of the faba bean shoot $\mathrm{N}$ $\left(\delta^{15} \mathrm{~N}\right.$ legume) to the $\delta^{15} \mathrm{~N}$ of the non- $\mathrm{N}_{2}$-fixing reference plants (which are assumed to reflect the $\delta^{15} \mathrm{~N}$ of the plant-available soil $\mathrm{N}$ [ $\delta^{15} \mathrm{~N}$ soil] $)$ using Eq. (1):

$\% \mathrm{Ndfa}=100 \times\left(\delta^{15} \mathrm{~N}\right.$ soil $-\delta^{15} \mathrm{~N}$ legume $) /\left(\delta^{15} \mathrm{~N}\right.$ soil $\left.-\mathrm{B}\right)$

where $B$ represents the $\delta^{15} \mathrm{~N}$ of faba bean shoots grown entirely reliant upon BNF for growth (Unkovich et al. 2008).

Generation of $B$-values for all seven of the faba bean varieties sown in the CSC (cvs, Babylon, Ben, Boxer, Fanfare, Fuego, Pyramid and Tattoo), and for pea cv. Corus was performed according to Unkovich et al. (2008) and Burchill et al. (2014). Plants were grown in a $1: 1(\mathrm{v} / \mathrm{v})$ mixture of autoclaved perlite and sand in $10 \mathrm{~L}$ pots in an unheated glasshouse from March to June. The pots were inoculated with a liquid culture of a mixture of $R l v$ isolates from the
CSC (see next section), and were fed weekly with an $\mathrm{N}$-free nutrient solution (Burchill et al. 2014), and watered daily or as required. As recommended by Rose et al. (2018), plants were harvested at early- to mid-podfill stage to match the plants sampled in the field, and $\delta^{15} \mathrm{~N}$ values were obtained from dried aerial parts as described above. $B$-values were also obtained for each year of the trial to ensure internal consistency in the data from the faba bean, reference plants, and $B$-values used to estimate $\% \mathrm{Ndfa}$ for each season (Table S3).

The amount of $\mathrm{N}$ fixed was then calculated from estimates of \% Ndfa, shoot dry biomass and $\mathrm{N}$ content $(\% \mathrm{~N})$ using Eqs. (2) and (3):

Legume shoot $\mathrm{N}=\% \mathrm{~N} / 100 \times($ legume shoot dry matter $)$

Amount shoot $\mathrm{N}$ fixed $=\% \mathrm{Ndfa} / 100 \times($ legume shoot $\mathrm{N})$

Estimating total crop $\mathrm{N}$ and residual $\mathrm{N}$ after grain harvest

Shoot-based calculations of $\mathrm{N}_{2}$ fixation underestimate total inputs of fixed $\mathrm{N}$ since substantial amounts of legume $\mathrm{N}$ can also be associated with, or released and derived from, the nodulated roots (Liu et al. 2019; 
Unkovich et al. 2010). In the case of field-grown faba bean, below-ground pools of $\mathrm{N}$ have been reported to represent between 24 and $40 \%$ of the total plant $\mathrm{N}$ (Unkovich et al. 2010). Given the well-known difficulties in obtaining accurate below ground crop $\mathrm{N}$ data (Liu et al. 2019; Unkovich et al. 2010), the total amounts of $\mathrm{N}_{2}$ fixed by the faba bean at the CSC at early to mid-podfill were estimated by multiplying the shoot values calculated using Eq. (3) by a factor of 1.52 to include the $\mathrm{N}$-content of the nodulated roots (Unkovich et al. 2010).

Total crop $\mathrm{N}$ at harvest was calculated from the grain yield, and this was then used to estimate the residual N. Grain was harvested from each $18 \mathrm{~m}$ strip using a standard combine harvester; sub-samples of dried grain were analysed for their $\% \mathrm{~N}$ using an elemental analyser as described above, and the total grain $\mathrm{N}$ was calculated by multiplying the dried grain mass by $\% \mathrm{~N}$. A mean harvest index (HI) value of 0.43 was calculated from the CSC faba bean crops in 2012 and 2013, a value which is typical for faba bean in northern Europe (Jensen et al. 2010; Sprent et al. 1977); this was used to calculate the dry biomass of the aerial parts of the crop comprising the stover plus the grains. An estimate of the total crop dry biomass (TCB) including the underground parts (roots and nodules) was then obtained by multiplying the dry biomass of the aerial parts by 1.52 to include the $\mathrm{N}$-content of the nodulated roots (Unkovich et al. 2010) using Eq. (4). The residual $N$ (i.e. the $N$ content of the stover plus roots) was estimated by subtracting the dry grain weight from the TCB and multiplying the resulting value by $0.6 \%$, which was the average $\% \mathrm{~N}$ across all varieties for the residual dry matter in the plots at the CSC in 2013 (5):

Total crop dry biomass $(\mathrm{TCB})=($ dry grain weight $/ 0.43) \times 1.52$

Legume residue $\mathrm{N}=(\mathrm{TCB}-$ dry grain weight $) \times 0.006$

Assessment of faba bean nodulation

To quantify nodulation at the CSC, nodules were removed from the root systems of the plants used for obtaining $\delta^{15} \mathrm{~N}$ values at mid-podfill stage; nodule dry weights were obtained by drying overnight at $70{ }^{\circ} \mathrm{C}$, and expressed as nodule biomass per plant. However, because it is difficult to excavate an intact root system from field-grown faba bean plants these data are only representative of the crown nodulation zone, which extends ca. $15 \mathrm{~cm}$ down the tap root.

Quantification of rhizobia in soils using a real-time qPCR assay

A principal aim of the study was to assess faba bean $\mathrm{BNF}$ at the CSC with reference to rhizobial soil populations in order to determine if the prolonged absence of legume cropping had a negative impact on these populations, and hence if it had a follow-on impact on BNF. The impact of compost application on rhizobial populations under the integrated treatment was also investigated. To this end, a relative real-time PCR method using an artificial reference "spike" (Daniell et al. 2012) and 16S rRNA and nodD gene primers (Macdonald et al. 2011) was employed to estimate Rhizobium leguminosarum 16S rRNA and Rhizobium leguminosarum sv. viciae nodD gene copy numbers in the four faba bean-cropped fields from 2012 to 2015.

Soil samples from 12 permanent GPS locations across faba bean fields were collected every March (before crop sowing) during 2012-2015 from the CSC farm platform as described by Hawes et al. (2018). In short, at each sample position, $1.5 \mathrm{~L}$ of soil was taken to a depth of $0.15 \mathrm{~m}$ using a soil auger or trowel, weighed and passed through a sieve with a mesh size of $10 \mathrm{~mm}$. Soil samples were dried overnight at $70{ }^{\circ} \mathrm{C}$ to determine their moisture content. Prior to drying, small sub-samples of the fresh soil (2 $\mathrm{mL}$ in volume) were flash frozen in liquid $\mathrm{N}_{2}$ and stored at $-80{ }^{\circ} \mathrm{C}$ for subsequent molecular analyses.

DNA was extracted from $\sim 0.25 \mathrm{~g}$ soil samples using the DNeasy PowerSoil Kit (Qiagen, Hilden, Germany) following the manufacturer's instructions, using a 2 min bead-beating step (Retsch MM300, Haan, Germany) at a frequency of 30 beats $\mathrm{s}^{-1}$. A $194 \mathrm{bp}$ (bp) fragment of the mutated 16S rRNA gene from Escherichia coli, which is routinely used as an artificial reference spike to account for DNA losses during DNA extraction from the soil (Daniell et al. 2012), was added to each soil sample at a concentration of $10^{9}$ copies per sample prior to DNA extraction.

The wild-type calibrator controls were generated by PCR amplification of $16 \mathrm{~S}$ rRNA and nodD gene fragments from soil DNA extracts using the primer 
sets F979+R1264 and F88+R443, respectively (Macdonald et al. 2011). Briefly, $1 \mu \mathrm{L}$ of soil DNA extract was used as template for PCR in a final reaction volume of $50 \mu \mathrm{L}$ containing: $1.25 \mathrm{U}$ GoTaq ${ }^{\circledR} \mathrm{G} 2$ DNA polymerase (Promega, Southampton, UK), 0.4 $\mu \mathrm{M}$ of each primer, $0.2 \mathrm{mM}$ of each nucleotide and 1x clear GoTaq® G2 Buffer (Promega, Southampton, UK). All reactions were performed on G-Storm GS1 thermal cyclers (GRI Ltd, Braintree, UK), with the following cycling conditions: initial denaturation at $95{ }^{\circ} \mathrm{C}$ for $2 \mathrm{~min}$; 35 cycles of $95{ }^{\circ} \mathrm{C}$ for $1.5 \mathrm{~min}$, $58{ }^{\circ} \mathrm{C}$ for $1 \mathrm{~min}$ and $72{ }^{\circ} \mathrm{C}$ for $1 \mathrm{~min}$; final extension of $72{ }^{\circ} \mathrm{C}$ for $15 \mathrm{~min}$. PCR products were gel purified using the MinElute Gel Extraction Kit (Qiagen, Hilden, Germany), and cloned into E. coli DH5 $\alpha$ (Invitrogen, Thermo Fisher Scientific, Waltham, Massachusetts, U.S.) using pGEM®-T Easy Vector System (Promega, Southampton, UK). Plasmid DNA was purified with QIAprep Spin Miniprep Kit (Qiagen, Hilden, Germany) and quantified using the Quant-iT PicoGreen dsDNA Assay Kit (Invitrogen, Thermo Fisher Scientific, Waltham, Massachusetts, U.S.). The number of copies of each gene was calculated using equations in Daniell et al. (2012).

Amplifications of the artificial spike, the $16 \mathrm{~S}$ rRNA and nodD calibrator controls and the $16 \mathrm{~S}$ rRNA and nodD genes were performed in triplicate using the LightCycler ${ }^{\circledR} 480$ SYBR Green I Master Kit (Roche, Burgess Hill, UK) following the manufacturer's instructions and using the set of primers of the amplified region of each reaction i.e. Mut-F+MutR for the spike (Daniell et al. 2012), F979+R1264 for 16S rRNA, and F88+R443 for nodD (Macdonald et al. 2011). All amplifications were carried out under the following conditions: an initial denaturation at $95^{\circ} \mathrm{C}$ for 15 min was followed by 42 cycles of $94{ }^{\circ} \mathrm{C}$ for $20 \mathrm{~s}, 58{ }^{\circ} \mathrm{C}$ for $30 \mathrm{~s}, 72{ }^{\circ} \mathrm{C}$ for $30 \mathrm{~s}$ and a single acquisition step at $81{ }^{\circ} \mathrm{C}$ for $5 \mathrm{~s}$. Melt curve analysis was performed between 55 and $95^{\circ} \mathrm{C}$.

In each PCR run, calibration curves were included for the 16S rRNA and nodD standards, and the artificial reference spike, by diluting these standards accordingly to give a concentration range from $10^{2}$ to $10^{8}$ copies per reaction in a 10 -fold dilution series. A reaction containing $1 \mu \mathrm{L}$ of each of these standards was included in each PCR run in duplicate. Crossing points were estimated using the Roche Diagnostic Systems software (Burgess Hill, UK) with default settings for the second derivative method, the copy number of each gene was calculated by regression analysis, corrected for individual PCR efficiencies calculated with LinRegPCR v 2020.0 (Ruijter et al. 2009) and expressed as number of gene copies $g^{-1}$ dry weight soil, assuming three copies of $16 \mathrm{~S}$ rRNA and one copy of nodD in the genome of R. leguminosarum (Macdonald et al. 2011). Although specificity of the $16 \mathrm{~S}$ rRNA and nodD primers for R. leguminosarum Rlv, respectively, was previously shown by MacDonald et al. (2011), their specificity was further confirmed by performing a BLASTn search in the NCBI database for both 16S rRNA primers. This showed that all sequences that had a match for both primers belonged to the genus Rhizobium with $R$. leguminosarum the most common species. A similar search carried out with both nodD primers only produced Rhizobium species with, again, $R$. leguminosarum the most frequent matches, and most importantly that all isolates were in sv. viciae (FerrandoMolina, unpublished).

Isolation of rhizobial symbionts from the CSC and other sites

A further aim of the study was to assess the genetic diversity of the rhizobia nodulating the faba bean at the CSC to determine their identity and hence their possible origins given the prolonged absence of legume cropping at this site. Symbionts were also assessed for their functional ability to promote legume growth in comparison with other local, Scottish, and British rhizobial isolates. Therefore, rhizobia were isolated from faba bean nodules that were sampled from the same fields as the BNF determinations in the CSC; three nodules per plant were sampled from three plants from each treatment (conventional and integrated) in each $18 \mathrm{~m}$ row in 2012 and 2013, and from one plant per row in 2014, 2015 and 2016. For comparison with the CSC isolates, rhizobia were also isolated from nodules on faba bean and pea crops growing in fields adjacent to the CSC, as well as from wild legumes belonging to the genera Lathyrus and Vicia that were growing in the field margins at the CSC and in its general locality in East Scotland. To place the CSC isolates into a wider geographical context, additional isolates were obtained from the soil in other agricultural and non-agricultural locations across the British Isles (Fig. 1, Table S1) by 
using pea, faba bean or lentil as "trap" plants. For this, surface-sterilized seeds $(70 \%[\mathrm{v} / \mathrm{v}]$ ethanol for $1 \mathrm{~min}$, followed by immersion in sodium hypochlorite $(2.5 \%[\mathrm{v} / \mathrm{v}] \mathrm{NaClO})$ for $5 \mathrm{~min}$, and then rinsing thrice in sterile distilled water (SDW)) were placed into autoclaved pots with a sterile vermiculite-perlite substrate plus a small quantity of the soil (100 g). The plants were watered with tap water as required. Plants were harvested after 4-6 weeks of growth, and pink healthy nodules, if present, were sampled from freshly washed roots. Five pots of uninoculated plants with just vermiculite-perlite were randomly distributed on the bench in the glasshouse or growth room, but none were nodulated and all died from N-starvation before harvesting the "inoculated" plants.

The nodules from each plant (CSC and others) were processed separately by surface sterilizing them in $70 \%[\mathrm{v} / \mathrm{v}]$ ethanol for $1 \mathrm{~min}$, followed by immersion in sodium hypochlorite $(2.5 \%[\mathrm{v} / \mathrm{v}] \mathrm{NaClO})$ for $3 \mathrm{~min}$, and then rinsing thrice in SDW. The nodules were then crushed using a sterile plastic pestle, and the nodule extracts were grown on Medium 79 (Fred and Waksman 1928), otherwise known as yeast mannitol agar or YMA (Vincent 1970), with Congo Red (CR) added to make YMA-CR plates, and incubated at $28{ }^{\circ} \mathrm{C}$ for $24-48 \mathrm{~h}$. Single colonies were picked off and individually streaked onto freshly prepared YMA-CR plates. Once pure isolates were obtained, a single colony from each YMA-CR plate was used to inoculate a sterile $5 \mathrm{ml}$ tryptone-yeast (TY) broth (Beringer 1974). Cultures were grown at $28{ }^{\circ} \mathrm{C}$ for 24-48 $\mathrm{h}$ in a shaking incubator (150 rpm). Liquid cultures at log phase (with an $\mathrm{OD}_{600}$ between 0.2 and 0.8 ) were used to prepare $25 \%[\mathrm{v} / \mathrm{v}]$ sterile glycerol stocks for long term storage at $-80^{\circ} \mathrm{C}$ and DNA extractions.

DNA extraction from nodule isolates

At $\log$ phase, $4 \mathrm{~mL}$ of each liquid culture was centrifuged at 5,000 $\times g$ for $15 \mathrm{~min}$ (Sigma 4K15, Dorset, UK) and the supernatant removed. The pellets were re-suspended in $0.4 \mathrm{~mL}$ of sterile TE buffer (10 mM Tris-Cl pH 8, 1 mM EDTA), 20\% [w/v] sodium dodecyl sulphate (SDS; final conc. $0.5 \%[\mathrm{w} / \mathrm{v}]$ ) and

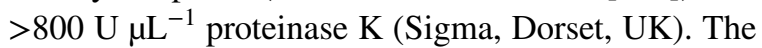
samples were incubated at $37^{\circ} \mathrm{C}$ for $1 \mathrm{~h}$ before addition of phenol:chloroform:isoamyl alcohol (25:24:1 [v/v/v]; Sigma, Dorset, UK). The samples were then vortexed (1 $\mathrm{min})$, followed by a $15 \mathrm{~min}$ centrifugation at 14,000 $\times g$ (Sigma 1-1 5 PK, Dorset, UK). To precipitate DNA, the aqueous phase $(200 \mu \mathrm{l})$ was combined with $10 \%$ [v/v] $3 \mathrm{M}$ sodium acetate (NaOAc; $\mathrm{pH}$ 5.2) and three volumes of isopropanol (Sigma, Dorset, UK) and incubated at $-80{ }^{\circ} \mathrm{C}$ for $15 \mathrm{~min}$, or at $-20{ }^{\circ} \mathrm{C}$ overnight. The DNA was pelleted by $15 \mathrm{~min}$ centrifugation at $14,000 \times g$ and washed with $200 \mu \mathrm{l}$ $70 \%[\mathrm{v} / \mathrm{v}]$ ethanol. Any residual liquid was removed after re-centrifugation for $1 \mathrm{~min}$ at $14,000 \times g$ by aspiration and next by drying at $37{ }^{\circ} \mathrm{C}$ for $15 \mathrm{~min}$. The DNA pellets were re-suspended in filter-sterilised milliQ water $(50 \mu \mathrm{l})$. All centrifugation steps were performed at $4{ }^{\circ} \mathrm{C}$.

Identification of rhizobia via sequencing of their $r r s$ (16S rRNA) and nodulation (nodA and $\operatorname{nod} D)$ genes

Primers and PCR thermal profiles used in this study are listed in Table S4. Each $30 \mu \mathrm{l}$ PCR reaction mixture used 1x Colorless GoTaq ${ }^{\circledR}$ Reaction Buffer (1.5 $\mathrm{mM} \mathrm{MgCl}_{2}$ final concentration; Promega, Southampton, UK), $0.2 \mathrm{mM}$ of each $\mathrm{dNTP}, 0.4 \mu \mathrm{M}$ concentration of each primer, 1.25 U of GoTaq DNA polymerase (Promega, Southampton, UK) and 1 $\mu \mathrm{L}$ DNA template. All reactions were performed on G-Storm GS1 thermal cyclers (GRI Ltd, Braintree, UK). To confirm successful amplification of the correct region, PCR products were resolved by electrophoresis on agarose gels with SYBR® Safe DNA Gel Stain (Invitrogen, Thermo Fisher Scientific, Waltham, Massachusetts, U.S.) and visualised using UV-illumination (FluorChem ${ }^{\circledR}$ Imager, Alpha Innotech, San Leandro, CA, U.S.). The PCR products were then purified using Illustra ExoProStar ${ }^{\mathrm{TM}}$ 1-step (GE Healthcare US77702V, Chicago, Illinois, U.S.) or using QIAquick-spin columns (Qiagen, Hilden, Germany), according to the manufacturer's recommendations, and sequenced using an ABI3730 DNA analyser with a $36 \mathrm{~cm}$ x 48 capillary array (Applied Biosystems ${ }^{\circledR}$, Thermo Fisher Scientific, Waltham, Massachusetts, U.S.). All sequencing was performed by the sequencing service at the James Hutton Institute. All the sequences were obtained with the Forward primer only, and these were inspected and edited manually (trimmed) using BioEdit Sequence Alignment Editor Version 7.2 (Hall 1999). The sequences 
were screened against databases using the nucleotide basic local alignment tool (BLASTN) queuing system (Altschul et al. 1997) 2.2.28 on the NCBI website.

Phylogenetic analysis of rhizobial isolates

Evolutionary analyses were conducted in MEGAX (Kumar et al. 2018). First, sequences were aligned using Clustal $\Omega$ (Sievers et al. 2011), then the best models were selected. Next, gene trees were inferred by using the Maximum Likelihood (ML) method and Tamura 3-parameter model with 1000 bootstrap replicates. Only bootstrap values $>50 \%$ are shown in the trees. All positions with less than $95 \%$ site coverage were eliminated (partial deletion option). A discrete Gamma distribution was used to model evolutionary rate differences among sites (5 categories) in the phylogeny of the nodD gene $(+\mathrm{G}$, parameter $=0.2861)$ and the nodA gene $(+\mathrm{G}$, parameter $=0.2672)$.

Assessment of the plant growth-promoting (BNF) potential of rhizobial isolates on pea and faba bean

All the isolates from the CSC plus those from other faba bean and pea crops assessed for their BNF contributions (Fig. 1), together with isolates from various wild legumes, were inoculated onto pea cv. Corus, and grown in a glasshouse to assess their ability to promote the growth of a typical $R l v$ host in the absence of soil N. Various reference strains were included for comparative purposes, including $V$. faba strains from the study of Mutch and Young (2004), strains isolated from faba bean in Ethiopia (Gebre Yohannes, unpublished), and strains isolated from lentil in Wiltshire, South-West England (this study). After the trials on cv. Corus, the 13 highest-performing strains were selected for further trials on pea cv. Kareni and on faba bean cv. Vertigo in comparison with a low-performing strain plus two standard laboratory strains. Controls were uninoculated plants. The experiments were performed using $1 \mathrm{~L}$ pots filled with a 1:1 mixture of autoclaved vermiculite and perlite; 3 replicate pots per strain/treatment. To prevent cross-contamination during watering the pots were covered in plastic film with a hole for the shoot to emerge. Plants were fed weekly with an $\mathrm{N}$-free nutrient solution (Burchill et al. 2014), and watered daily or as required. Plants were harvested at the flowering stage ( $49 \mathrm{~d}$ after inoculation for pea and $70 \mathrm{dpi}$ for faba bean) and above ground biomass quantified as a proxy for BNF (Unkovich et al. 2008).

Sampling of faba bean and pea crops from a range of British farms

To extend the relevance of our single, detailed field study, and to explore BNF in faba bean and pea more generally across commercial crops in Britain, eleven additional sites (five for faba bean and six for pea) were selected following a survey of pulse growers conducted in collaboration with the Processors and Growers Research Organisation (PGRO) (Fig. 1). Participating growers were advised how to sample aerial parts of their faba bean and/or pea crops together with associated non-legume weeds and/or volunteers as for the CSC (see above); these samples were sent to the James Hutton Institute together with soil samples from the same fields for rhizobial trapping trials (see earlier). The plant samples were treated as per the CSC faba bean samples, except that only their $\delta^{15} \mathrm{~N}$ values were determined, which were then used to calculate $\% \mathrm{Ndfa}$. $B$-values were determined as described above for any faba bean and pea varieties that had not already been obtained for the CSC \%Ndfa calculations.

\section{Statistical analyses}

For analysis of the CSC data, the Restricted Maximum Likelihood (REML) and the linear mixed model approach procedures were performed in GenStat for Windows 21th Edition (VSN International Ltd., Hemel Hempstead, U.K.) for shoot biomass and $\% \mathrm{~N}$ of the faba bean grown in the four-year rotation (2012-2015), as described previously by Freitag et al. (2018). In short, Year+Variety*Treatment effects were fitted as fixed effects. Terms: Year.Variety + Year.Treatment + Year.Strip.Treatment (accounting for differences between strips in a half-field) + Year.Rep (accounting for trends down the field) + Year. Treatment.Rep (accounting for trends down a half-field of the field halves) were included as random effects. As the grain yield, grain $\mathrm{N}$ and residue $\mathrm{N}$ were only measured from whole strips, the random effects of Variety, Rep and Strip were excluded in REML for these variables. As there were changes to the selection of varieties grown for field beans between years, cv. Maris Bead, which was present in 
only one year (2012), was excluded from the analysis. Multiple comparisons were carried out using Fisher's unprotected least significant difference test. Details are given in File S1A.

An analysis of variance (ANOVA) and Bonferroni test in GenStat for Windows 20th Edition (VSN International Ltd., Hemel Hempstead, U.K.) were used to adjust for multiple comparisons in assessment of faba bean nodule and root dry weight. Means and standard errors were calculated for each year, variety of faba bean, and treatment. However, as different varieties were used each year, the means for years were not statistically compared.

The ANOVA analysis of the qPCR data was carried out with $\mathrm{R}$ version 3.5.1 ( $\mathrm{R}$ core Team 2013) implemented on RStudio version 1.1456 (R Studio Team 2015). When the ANOVA results were significant, package multcomp version 1.4.10 (Hothorn et al. 2008) was used to carry out the post-hoc pairwise comparison Tukey's Honest Significant Difference (Tukey's HSD) test for comparing means between fields. Additionally, packages dplyr version 0.8.3 (Wickham et al. 2019) and ggplot2 version 3.1.0 (Wickham 2016) were used for data handling and visualisation, respectively. Details are given in File S1B.

\section{Results}

Nitrogen fixation and nodulation by faba bean in an experimental rotation incorporating compost instead of fertilizer

Variations in crop biomass, shoot $\mathrm{N}$, shoot ${ }^{15} \mathrm{~N}$, and grain yield reflected the seasonal variations in weather over the four years of the CSC rotation tested in the present study (2012-2015) (Fig. S1), with 2014 being exceptionally high in terms of all growth parameters, including grain yield (Figs. 2, S2; Table S5). In terms of BNF, the \%Ndfa values at early to mid-podfill stage were consistently high in each season, ranging from c. $80 \%$ in 2013 to $>90 \%$ in 2014 and 2015 (Table S5); the values from the integrated treatment were generally higher than those from the conventional treatment, but this was only significant in 2012 when the \% Ndfa of the conventional and integrated plants were 80.99 and 90.52, respectively (Table S5). The BNF data closely followed the same pattern as shoot biomass and shoot $\mathrm{N}$ content, with the crops in 2012 and 2013 fixing less than half those in 2014 and 2015 (Figs. 2B, S2, Table S5). In 2014, by including projected values for the underground contribution using the root factor calculated by Unkovich et al. (2010), it was estimated that faba bean fixed more than $300 \mathrm{~kg} \mathrm{~N}^{-1}$ under both conventional and integrated management (Table S5, Fig. S2D, E). There was a significant interaction between management type and faba bean genotype on shoot fixed $\mathrm{N}$ and total plant fixed $\mathrm{N}$ in 2014 and 2015, with BNF by cvs. Babylon and Boxer significantly benefitting from the integrated treatment (Fig. S2B-E, Table S5).

At crop harvest, grain $\mathrm{N}$ and estimates of residual $\mathrm{N}$ (Fig. 2D, Table S5) followed the same patterns as grain yield; in the highest-performing year (2014) more than $100 \mathrm{~kg} \mathrm{~N} \mathrm{ha}^{-1}$ was estimated to be left in the crop residues after the grain had been harvested (Fig. 2D). There were no significant differences between treatments in dry grain yield, grain $\mathrm{N}$ and residue $\mathrm{N}$.

Overall, there were no significant differences between treatments in each of the three years that were analysed for nodule and root dry weights (2012, 2013 and 2014), although there were significant differences between varieties in 2012 and 2013 (Table S6).

Quantification of rhizobia in soils subsequently cropped with faba bean

Soil populations of the potential symbionts of faba bean at the CSC were assessed every March in the years 2012-2015. The concentration of R. leguminosarum $16 \mathrm{~S}$ rRNA and Rlv nodD gene copy numbers (Fig. 3a) did not differ between conventional and integrated treatments within each field cropped with faba bean, but there were significant differences between years for both $R$. leguminosarum 16S rRNA (Fig. 3a) and Rlv nodD (Fig. 3b) gene copy numbers. The faba bean-cropped field in year 2012 had the highest concentrations of both markers $\left(1.62 \times 10^{6} R\right.$. leguminosarum 16S rRNA g dry soil $^{-1} ; 1.93 \times 10^{5}$ Rlv nodD g dry soil ${ }^{-1}$ ) whilst the field in 2015 had the lowest concentration for $R$. leguminosarum $16 \mathrm{~S}$ rRNA $\left(6.42 \times 10^{5}\right.$ Rleg $16 \mathrm{~S}$ rRNA g dry soil $\left.{ }^{-1}\right)$. The fields in 2013 and 2015 had the lowest concentration 
of Rlv nodD $\left(1.31 \times 10^{5}\right.$ and $1.21 \times 10^{5} \mathrm{Rlv} \operatorname{nodD} \mathrm{g}$ dry soil $^{-1}$, respectively). Despite the differences observed in gene copy number of both markers, the ratio of the copy numbers of Rlv nodD per copy of $R$. leguminosarum 16S rRNA (Fig. 3c) was similar in the faba bean-cropped fields in 2012 and in 2013, but there was a significantly higher ratio in the faba bean-cropped field in 2014 (conventional treatment only), and most particularly in 2015 wherein this field housed the highest proportion of Rlv nodD per copy of $R$. leguminosarum 16S rRNA (19.84\% and $17.98 \%$ in the conventional and integrated treatments, respectively).

Genetic diversity of rhizobia isolated from faba bean in comparison to other cultivated and wild legumes

The genetic diversity of the rhizobia nodulating faba bean at the study site from 2011 to 2016 was determined, and then compared to neighbouring localities and other sites across Britain. In total, 144 rhizobial isolates were obtained from nodules on faba bean grown at the CSC, as well as from faba bean and pea crops neighbouring the CSC, from wild legumes in the CSC field margins, and from other cropped and non-cropped sites in Scotland and England (Table S1, S8). Reference strains from other parts of Britain included six faba bean strains from Yorkshire in Northern England (Mutch and Young 2004), the well-studied laboratory standard strain Rlv 3841 (Young et al. 2006), and strain rcr1045 which is commonly used as the basis of commercial faba bean and/or pea inoculants. Some non-British reference strains were also included in the analyses to provide an international context; these included seven strains isolated from faba bean in Ethiopia, and a strain from Lathyrus sativus in the USA. All the 160 strains in the study were identified as belonging to the genus Rhizobium based on sequences of their 16S rRNA (rrs) genes (Table S1, S8). Highest similarity BLAST hits suggested that they were all close to $R$. leguminosarum, which is the most commonly isolated symbiont of this group of legumes in Northern Europe (Ampomah and Huss-Danell 2017; De Meyer et al. 2011; Mutch and Young 2004). However, as information about the symbiotic properties of Rhizobium resides in the transferable symbiotic plasmid (pSym) which contains the nitrogen fixation (nif) and nodulation (nod) genes (Young et al. 2006), in order to better understand the genetic diversity of the isolates, two nodulation genes (nodA, nodD) were then sequenced and compared to those in the database.

The nodA and nodD phylogenies showed a high level of congruence, with an almost identical distribution of the isolates between two large and distinct clades for both genes; these were closely related to strains previously isolated from faba bean, pea, and other Vicia, Lathyrus and Lens species (Figs. 4, S3, S4, S5). Taking the nodD phylogeny as an example (Figs. 4, S3), Group I comprised mainly strains from pea, lentil and wild legumes growing in the islands of Orkney and Skye through mainland Scotland into northern (Yorkshire; Mutch \& Young (2004)) and southern (Wiltshire, Norfolk and Cambridgeshire) England. It included all the strains isolated from wild legumes (Lathyrus pratensis L. and Vicia cracca L.) in the CSC field margins (JHI27, JHI32, and JHI35) (Fig. S3). The only $V$. faba isolates in Group I were some of those sampled from the CSC in 2013 (16 strains), two CSC strains from 2015, JHI983 from a farm neighbouring the CSC, a single strain from the centre of England (JHI1147), and four of the Ethiopian strains. Group I also harboured strains from the USA (pea), Poland (pea), and Sweden (wild legumes). Group II contained most of the $V$. faba isolates from the CSC (sampled in the six years from 2011 to 2016, and including the 2013 isolates not clustered within Group I) and from $V$. faba cultivated in farms neighbouring the CSC (e.g. JHI981, JHI982 and JHI984), as well as isolates trapped from pea grown in CSC soils from 2014 (Fig. S3). Group II also included most of the faba bean isolates from other parts of Scotland and England, as well as several pea and lentil isolates, together with $V$. faba strains from Ethiopia, Spain, Canada, and China. All strains in Group II were closely related to the sequenced laboratory strain rlv3841. In addition to the two large groups, four smaller ones, Groups III - VI, were also apparent (Figs. 4, S3). Group III contained the type strain of $R l v$, USDA $2370^{\mathrm{T}}$ (isolated from $V$. faba in Tunisia) together with four strains from the same location in Angus, Scotland, which were isolated from nodules on pea (JHI10, JHI13, JHI1438) or V. sativa (JHI47). Group IV consisted of JHI1249 isolated from pea nodules in Orkney (Scotland) together with strains from Lathyrus sativus in the USA (JHI1084), V. faba in China and Jordan, and lentil in Bangladesh (type strains of $R$. bangladeshense, $R$. binae, and R. lentis). 


\section{a}

Shoot biomass (t ha-1)

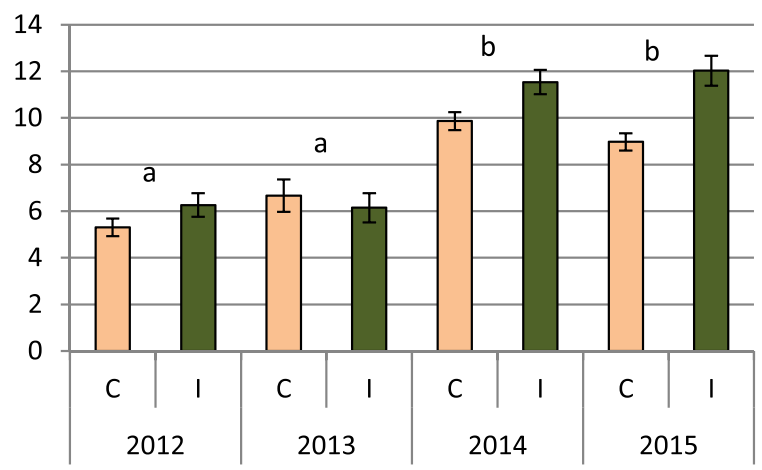

C

Dry grain yield $\left(\mathrm{t} \mathrm{ha}^{-1}\right)$

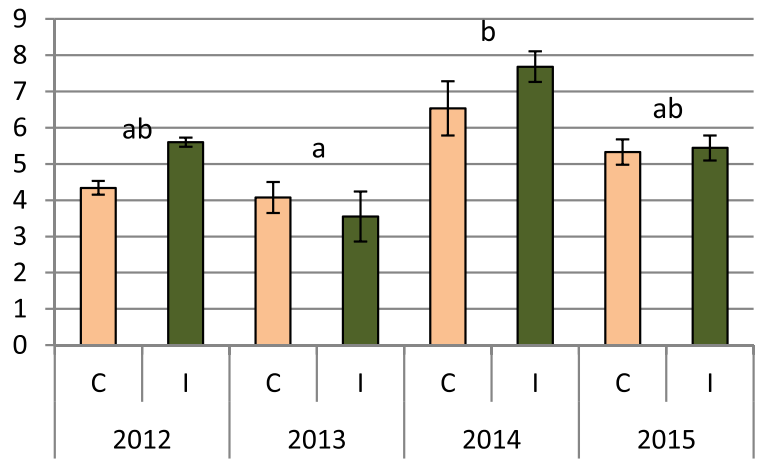

Fig. 2 Shoot dry biomass (a), total crop $\mathrm{N}$ and total crop fixed $\mathrm{N}$ at mid pod-fill (b), dry grain yield at harvest (c), and grain $\mathrm{N}$ and residual $\mathrm{N}$ at harvest (including roots) (d) of faba bean during the 2012-2015 growing seasons at the Centre for Sus-

Group V consisted of a single UK strain, JHI2450, isolated from pea grown in soil from Norfolk (east England), together with Swedish and Russian strains isolated from wild legumes (Ampomah and HussDanell, 2017). Finally, Group VI comprised only JHI2449, a single pea strain from Norfolk in southeast England.

Plant growth-promoting (BNF) potential of the rhizobial isolates on pea and faba bean

Almost all the isolates and reference strains (147) were tested in the glasshouse for their ability to promote the growth of pea (Fig. S6), a relatively "promiscuous" $R l v$-nodulating species

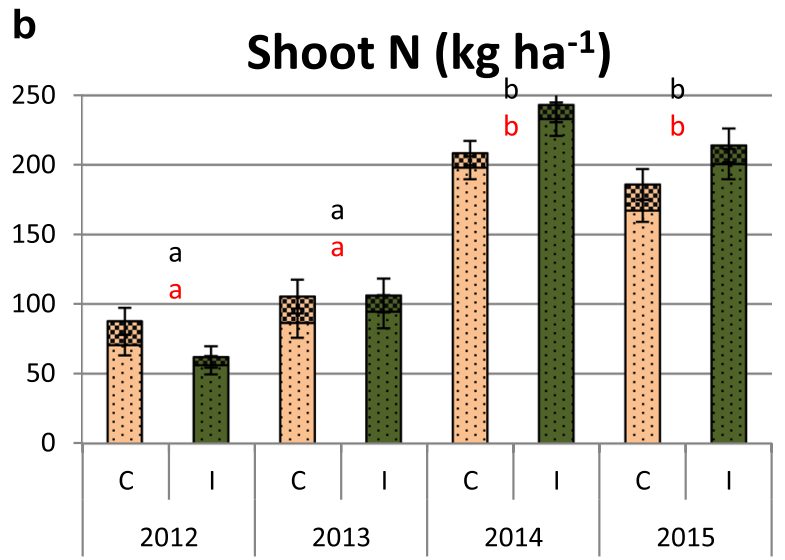

Thotal shoot $\mathrm{N}$ ab $\mathrm{Q}$ Fixed shoot $\mathrm{N}$ ab

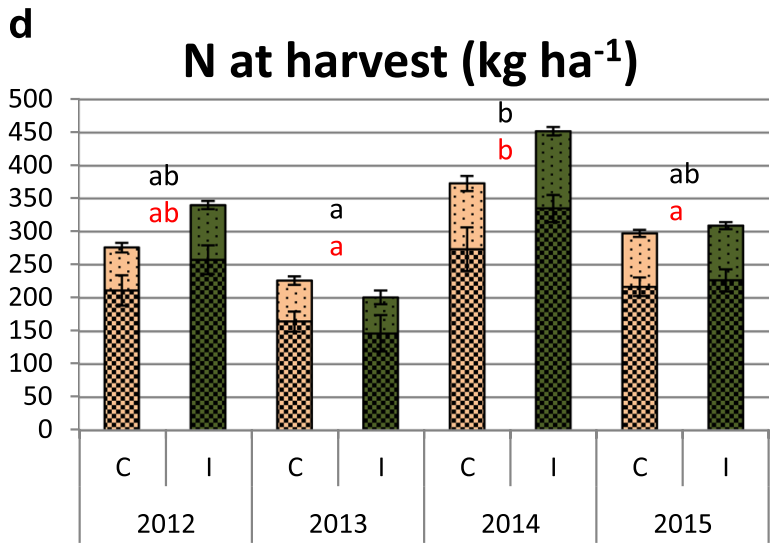

$\mathrm{QN}$ in residues ab $\mathrm{g}$ Grain $\mathrm{N} a b$

tainable Cropping (CSC) farm platform with conventional (C) or integrated (I) management. Data are means \pm standard error. Significant differences $(\mathrm{p}<0.05)$ are indicated with different letters

(Mutch and Young 2004). All the isolates nodulated cv. Corus, but some were particularly effective in terms of promoting shoot dry weight e.g. many resulted in plants with shoot dry weights that were double those inoculated with the standard laboratory strains, Rlv 3841 and rcr1045. Fourteen of the isolates were selected for further trials on pea cv. Kareni (Fig. 5A) and on faba bean cv. Vertigo (Fig. 5B). The highest performing strain in terms of growth promotion on both pea varieties was JHI388; this strain, as well as other strains that promoted the highest measured growth on pea cvs Corus or Kareni were isolated from various hosts, including faba bean (JHI388, JHI370, VF5), the rare wild species Vicia lutea 
Fig. 3 Quantifications of $R$. leguminosarum $16 \mathrm{~S}$ rRNA marker (a) and Rlv nodD (b) given as gene copy number per $\mathrm{g}$ of dry soil per year in fields cropped with faba bean during the 2012-2015 growing seasons at the Centre for Sustainable Cropping (CSC) farm platform with conventional (C) or integrated (I) management. The ratio of $R l v$ nodD per $R$. leguminosarum $16 \mathrm{~S}$ rRNA is also shown (c). Each pair of boxplots with the same letter did not show significant differences (p-value $<0.05$ ) between each other according to the results of Tukey's HSD.

Outliers are data points more than $1.5 \cdot I Q R$ (interquartile range) above the third quartile (Q3) or below the first quartile (Q1). Low outliers are below the first quartile (Q1-1.5·IQR) and high outliers are above the third quartile $(\mathrm{Q} 3+1.5 \cdot \mathrm{IQR})$ a

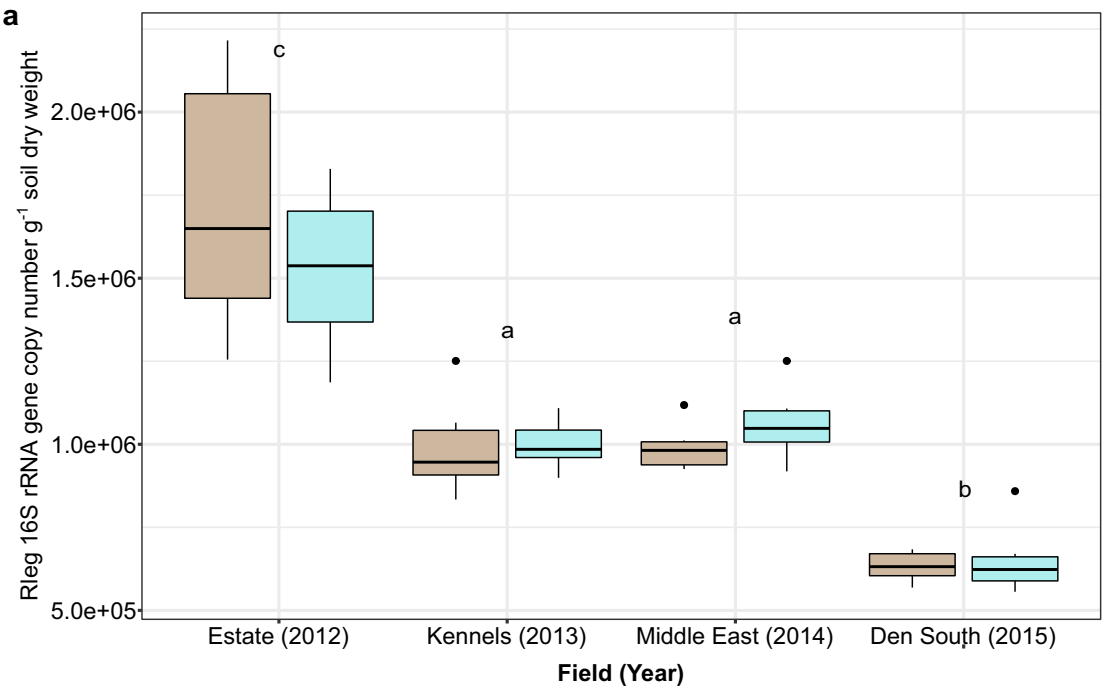

b

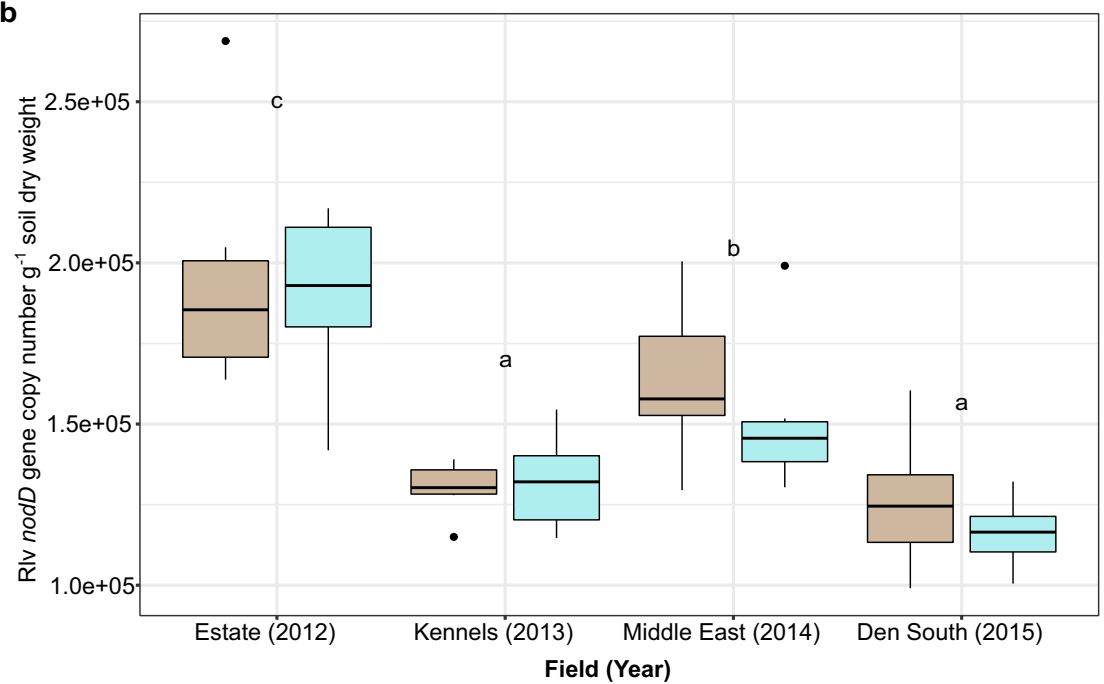

C

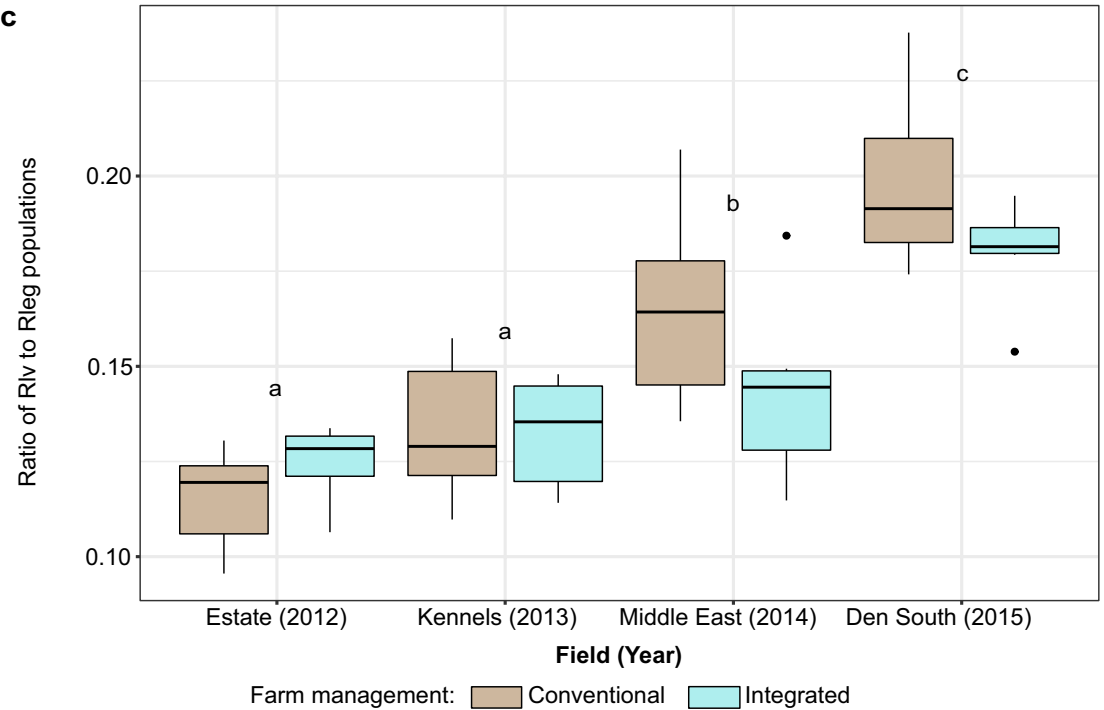


(JHI42), and pea (JHI13). The five strains that promoted the most growth of faba bean cv. Vertigo were not the same as those that promoted the most growth of pea, and they were also isolated from a wide range of hosts, including $V$. tetrasperma (JHI24), faba bean (VF2), pea (JHI974, Rlv 3841), and Lathyrus linifolius (JHI1093). The Rlv strains that promoted the most growth of either legume host did not fall into any particular nodAD clade (Table 2).

Estimates of the contribution of BNF (\%Ndfa) to faba bean and pea crops in other locations in the British Isles

The $\delta^{15} \mathrm{~N}$ of faba bean and pea grown on commercial farms from the northern Isles of Scotland (Orkney) down through to southern England were used to estimate \%Ndfa at these various locations (Fig. 1). In all cases, the difference between the legumes and the associated non-legume reference plants were indicative of high contributions from BNF with estimates ranging from 82 to $96 \%$ for faba bean and $58-97 \%$ for pea (Table S7).

\section{Discussion}

Faba bean can provide most of its nitrogen requirements via BNF in a northern temperate cropping system

The CSC provided a suitable platform for assessing the ability of faba bean to fix $\mathrm{N}$ in Northern Britain. Although several studies have been conducted in other European countries, as well as in North America and Australia (Denton et al. 2013; Giambalvo et al. 2012; Hossain et al. 2016; Jensen et al. 2010; Van Zwieten et al. 2015), the present field scale study is the first to provide direct experimental evidence over several consecutive seasons that faba bean can fix almost all of its $\mathrm{N}$-requirements under the relatively wet and cool climate of the British Isles.

The \%Ndfa in the CSC trial were generally high, demonstrating that most of the plant $\mathrm{N}$-requirements were met by $\mathrm{BNF}$, as has been observed in many other locations in Europe and elsewhere in the world (Denton et al. 2013; Jensen et al. 2010; Peoples et al. 2021). The differences in \%Ndfa between 2012 (c. $80 \%$ ) and 2013 (c. 90\%) were not reflected in their total $\mathrm{N}$ which were very similar; this suggests that the 2013 crop assimilated at least $40 \mathrm{~kg} \mathrm{ha}^{-1}$ of soil $\mathrm{N}$ at mid-podfill stage, which corresponds to the available $\mathrm{N}$ in the field at the start of the 2013 season. One possibility is that the cold spring in 2013 inhibited nodulation and BNF, so that the plants had to compensate for the lack of fixed $\mathrm{N}$ by utilising the available soil $\mathrm{N}$ until the onset of the warmer summer weather (Burchill et al. 2014). In all the other years the high $\%$ Ndfa demonstrated that uptake of available $\mathrm{N}$ in the soil was very low, probably less than $30 \mathrm{~kg} \mathrm{ha}^{-1}$. Faba bean is, however, particularly effective at fixing $\mathrm{N}$ when grown in soils with high levels of applied mineral N. For example, $300 \mathrm{~kg} \mathrm{ha}^{-1}$ will completely inhibit BNF by most legume crops, but faba bean can maintain \%Ndfa levels above $40 \%$ at this fertiliser rate (Guinet et al. 2018).

The quantities of $\mathrm{N}$ fixed by faba bean in the present study were generally within the range previously reported in northern Europe and elsewhere i.e. 100-250 kg N ha ${ }^{-1} \mathrm{yr}^{-1}$ (Jensen et al. 2010), although there were statistically significant variations from season to season. In 2012 and 2013, at $100 \mathrm{~kg} \mathrm{~N} \mathrm{ha}^{-1} \mathrm{yr}^{-1}$ the BNF values were at the lower end of the range of previous estimates, but in 2014 and 2015 they were much higher, ranging from 250 to $350 \mathrm{~kg} \mathrm{~N} \mathrm{ha}^{-1} \mathrm{yr}^{-1}$. These differences can be attributed to biomass production by the early- to mid-podfill stage (the stage at which $\mathrm{BNF}$ is maximal), as at high \% Ndfa $(>80 \%)$ $\mathrm{BNF}$ is essentially a function of the $\% \mathrm{~N}$ and biomass of the shoots (Unkovich et al. 2010). Biomass production was low in 2012 and 2013 owing to poor growing conditions (flooding in 2012 and a prolonged cold spring followed by a hot and dry summer in 2013), but in 2014 (and to a lesser extent in 2015) weather conditions were ideal for crop growth, and consequently plant biomass and grain yields were high. This was also reflected in the total crop $\mathrm{N}$ at the final harvest which is comprised of grain $\mathrm{N}$, as well as the $\mathrm{N}$ left in the crop residues (including the roots) of over $100 \mathrm{~kg} \mathrm{~N} \mathrm{ha}^{-1} \mathrm{yr}^{-1}$; these $\mathrm{N}$-residue values are within the range predicted or measured by other studies of nodulated field-grown faba bean (Denton et al. 2013; Jensen et al. 2010).

Commercial faba bean and pea crops sampled in other parts of the British Isles also had generally high dependence on BNF. None of the fields in which 


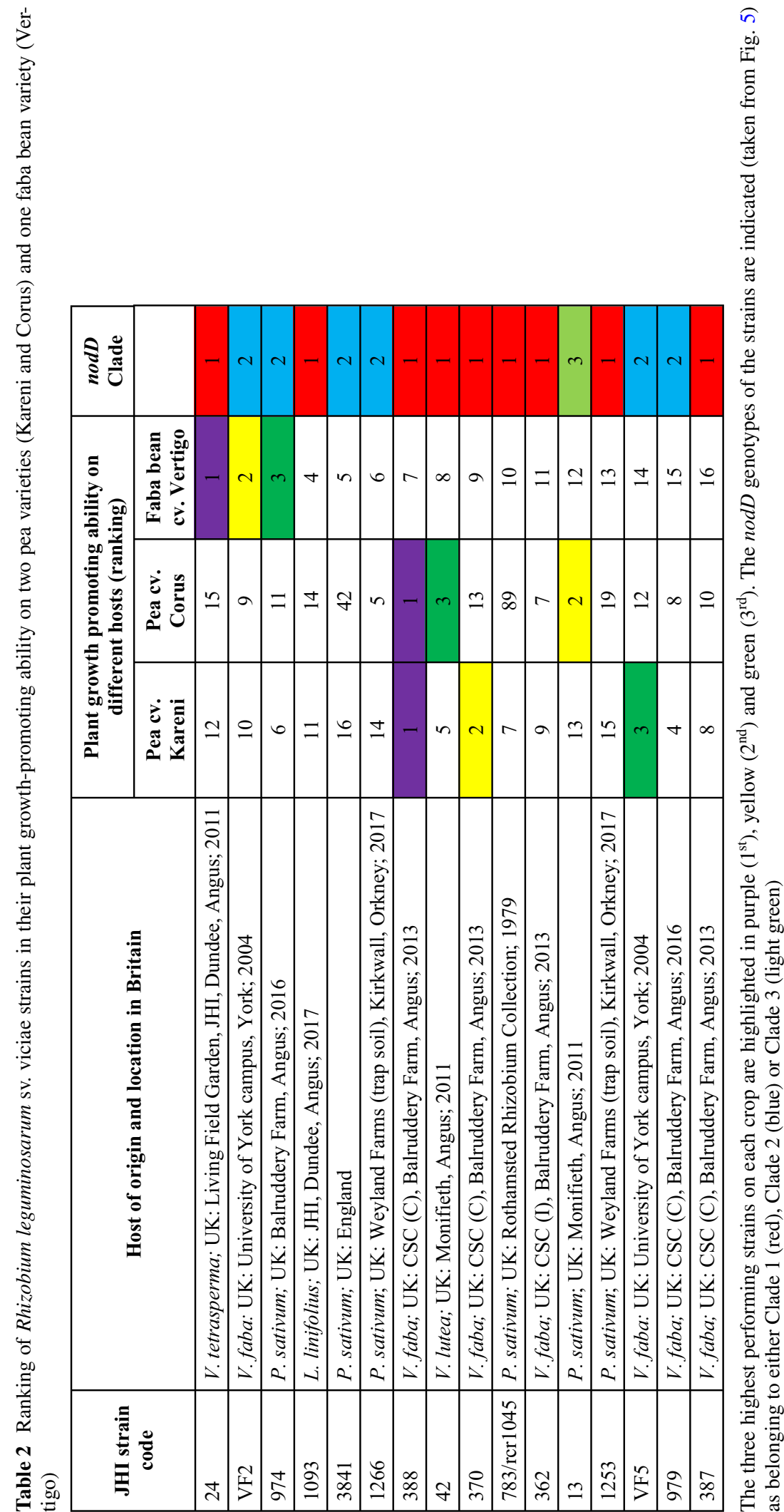


Fig. 4 Collapsed phylogeny of the nodD gene based on 192 nucleotide sequences ( 588 positions in the final dataset) from rhizobia isolated from nodules on species of Vicia, Pisum, Lathyrus and Lens at all sites sampled in the British Isles. The tree is rooted with Rhizobium leguminosarum bv. trifolii WSM2304. The type strains are shown with a ' $\mathrm{T}$ ' at the end of each strain code. The trees are drawn to scale, with branch lengths measured in the number of substitutions per site. The pie charts indicate number of strains per group isolated from different legume hosts: Vicia faba (red); Pisum sativum (green); Lens culinaris (blue); other Vicia species (brown); Phaseolus vulgaris (pink); Lathyrus species (grey)

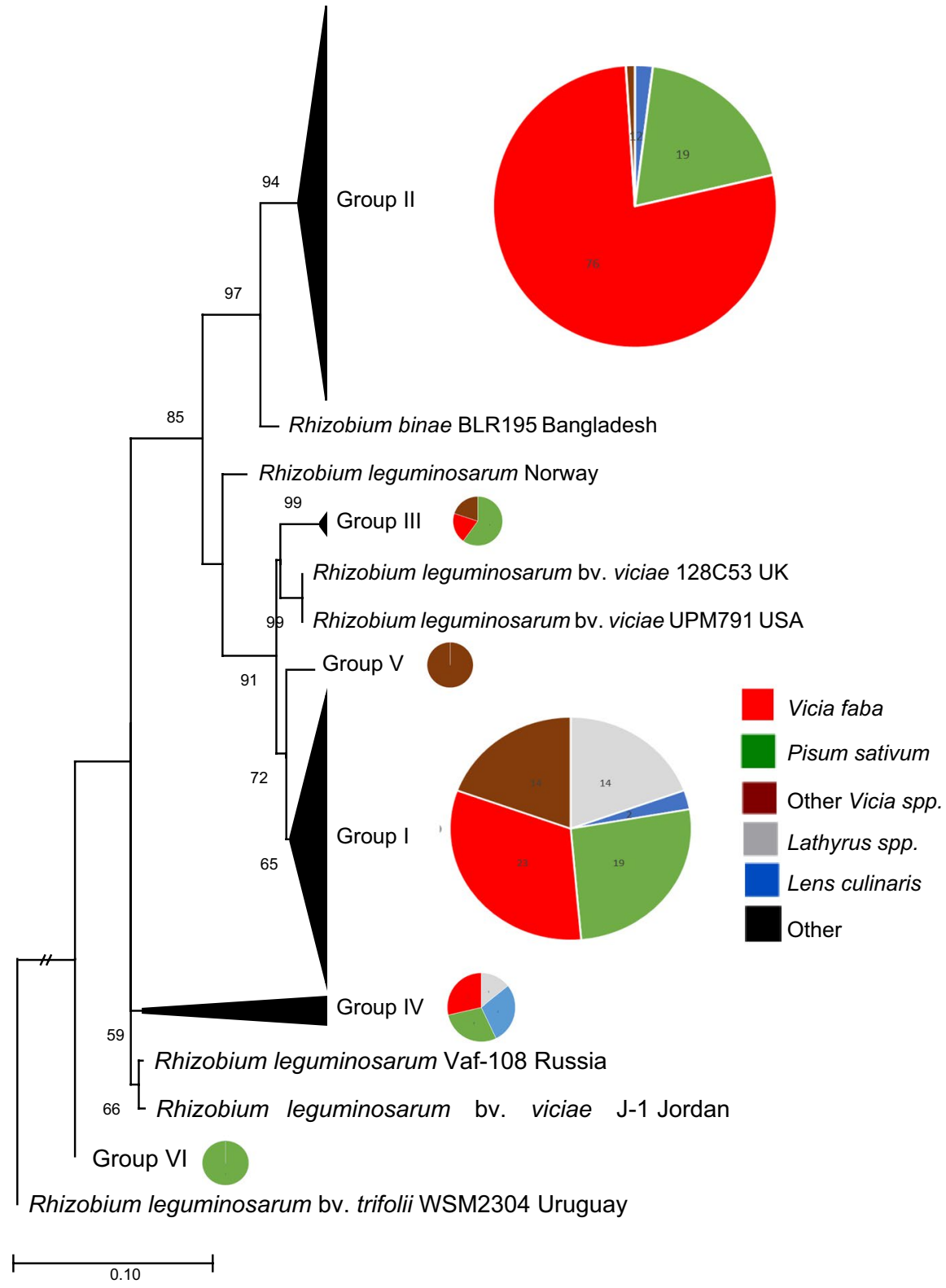

these crops were grown received applications of mineral $\mathrm{N}$ fertilisers, and so these data also support the earlier contention that faba bean and pea in the British Isles can provide most of their N-requirements through BNF. Such confirmatory data from actual farm locations are considered to be critical in assessing if experimental \%Ndfa values are valid in terms of calculating global inputs of BNF (Peoples et al. 2021).
Integrated crop management can enhance BNF by some faba bean varieties in a northern temperate cropping system

A positive effect of the integrated treatment on the BNF of faba bean at the CSC was only apparent in the high-yielding years, but it was especially evident in 2014 where it resulted in an estimated additional 50-100 $\mathrm{kg} \mathrm{N} \mathrm{ha}^{-1} \mathrm{yr}^{-1}$ being fixed, depending on 


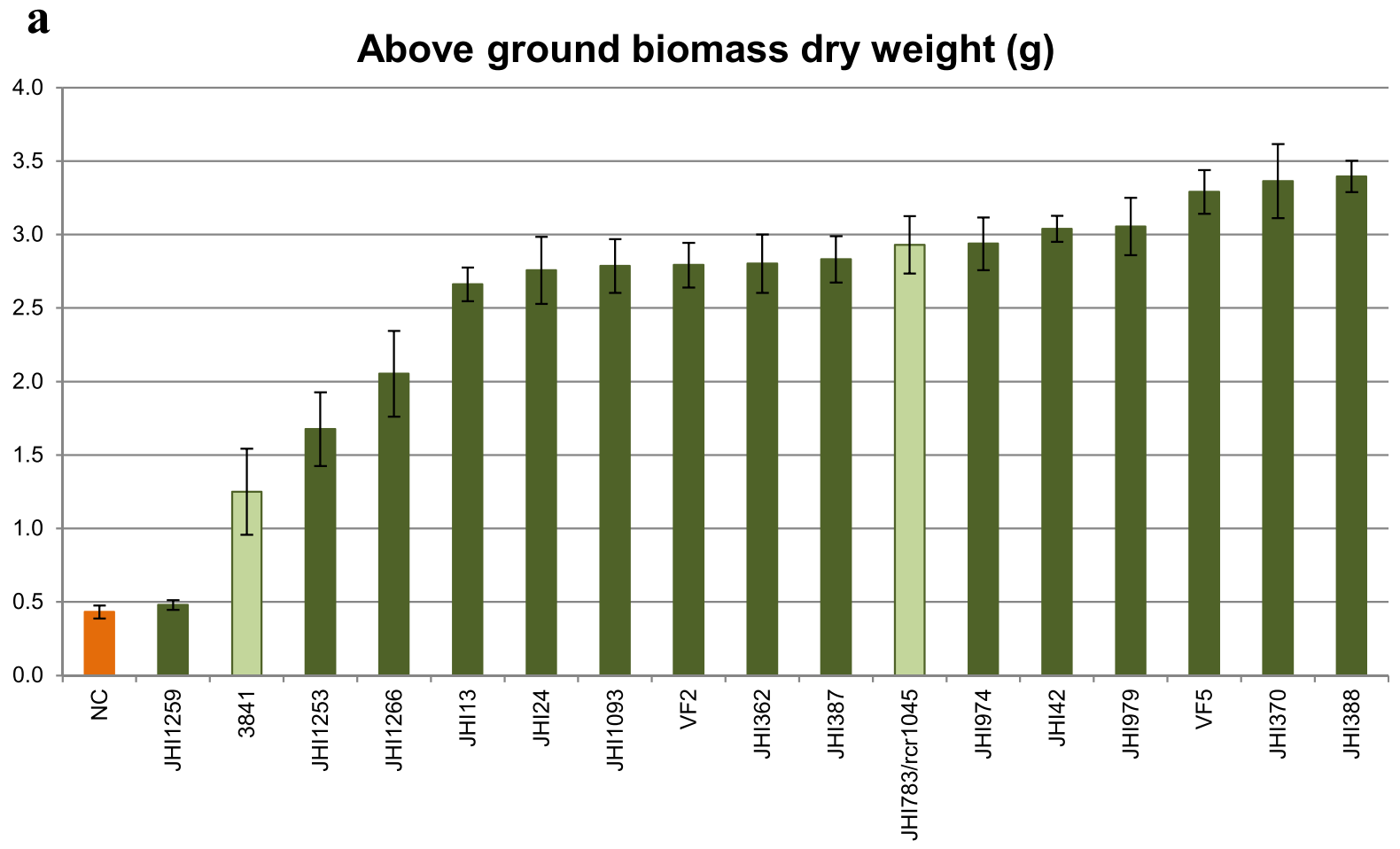

b

Above ground biomass dry weight (g)

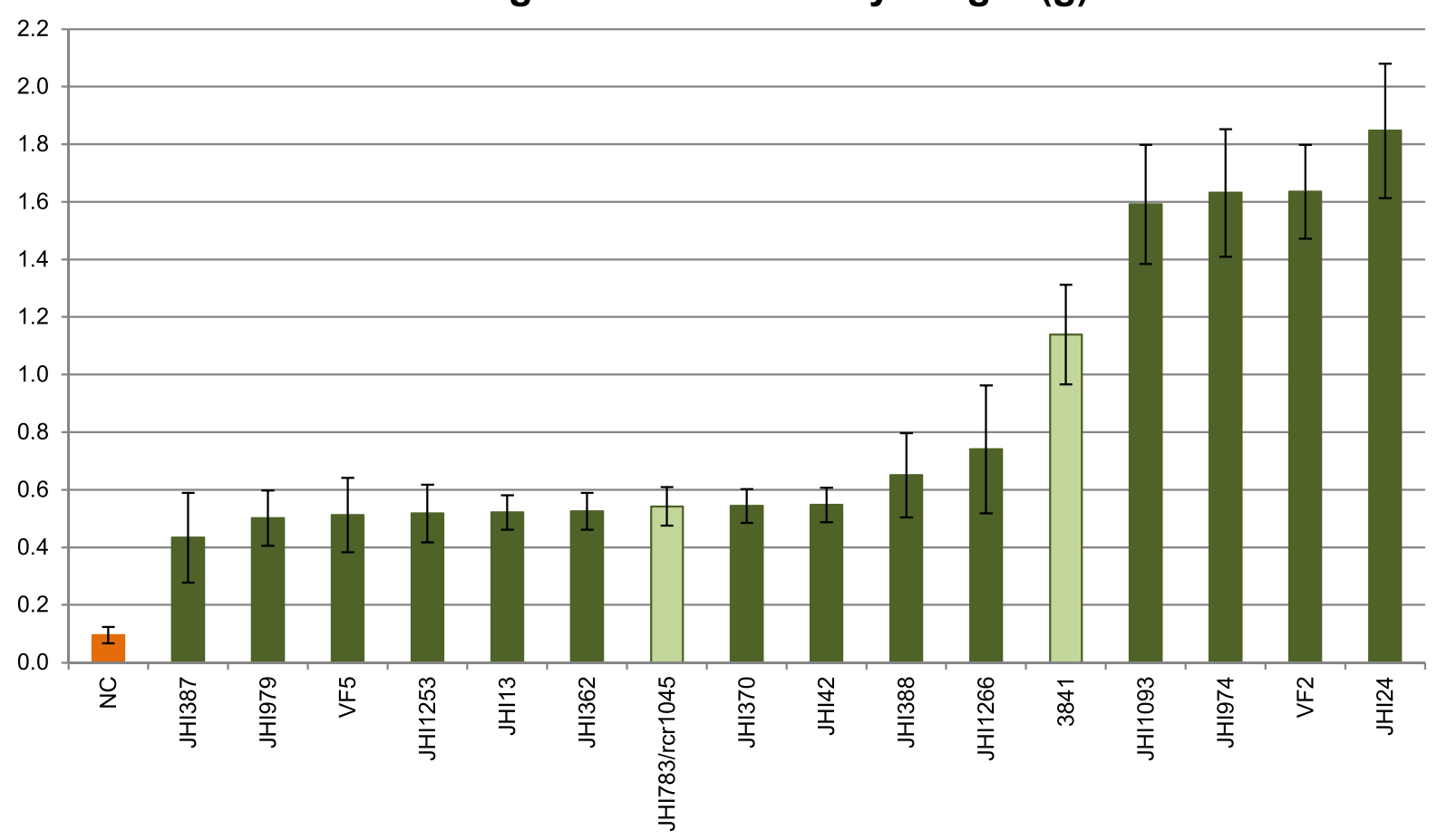


4Fig. 5 Effect of inoculation of rhizobial strains on the aerial dry biomass of pea cv. Kareni (a) and faba bean cv. Vertigo (b). Data from the reference strains, rcr1045 and rlv3841, are indicated in light green, and non-inoculated controls (NC) in orange. Data are means \pm standard error

variety (Fig. S2c, e). The positive effects of integrated management on BNF in 2014 and 2015 cannot be explained in terms of either rhizobial populations (both absolute and in terms of the symbiosis gene, nodD) nor nodulation, as the mass of nodules per plant was not significantly increased by this treatment. This is surprising given the strong link observed between N-demand and nodule numbers/ mass in other legumes, such as pea (Voisin et al. 2010). It possibly suggests that the rate of BNF per nodule was increased in the integrated field halves in 2014 and 2015 where high BNF was driven by high demand for $\mathrm{N}$ to supply the rapidly growing plants in these years where temperatures and precipitation were close to optimum for crop development. An increased $\mathrm{BNF}$ rate might have been due to the main component of the integrated treatment, the compost, raising soil $\mathrm{pH}$, carbon stocks, and moisture retention, and also by acting as a controlled-release fertilizer, supplying increased concentrations of the main plant growth-limiting macronutrients ( $\mathrm{P}$ and $\mathrm{K}$ ) (Hawes et al. 2018), and possibly micronutrients essential for the BNF process, particularly Mo (Van Zwieten et al. 2015). Another clue as to the mechanism behind a possible positive effect of Integrated management on $\mathrm{BNF}$ is given by the interaction between this treatment and the faba bean varieties, with cvs Boxer and Babylon responding particularly well; this suggests that there is a genetic component underlying the ability of faba bean to benefit from the improved soil conditions.

Rhizobia populations in the CSC soils were sufficient to support faba bean BNF despite a 50-plus year absence of legume crops

Populations of $R$. leguminosarum in the CSC soils in the four years from 2012 to $2015\left(10^{5}\right.$ to $10^{6} \mathrm{~g}^{-1}$ soil) were similar to those obtained using most probable number (MPN) estimates in Denmark (Jensen and Sørensen 1987), and England (Hirsch 1996; Nutman and Hearne 1979), and in England using both MPN and qPCR with the same primer sets used in the present study (Macdonald et al. 2011). It should be noted that the $16 \mathrm{~S}$ rRNA primers potentially recognize all $R$. leguminosarum cells in the soil, including both $R l v$ and clover-nodulating strains of $R$. leguminosarum sv. trifolii $(R l t)$, as well as non-symbiotic strains (Hirsch 1996), whereas data obtained using the nodD primers are more useful in specifically evaluating populations of faba bean-nodulating $R l v$ (Macdonald et al. 2011); these were approximately $10^{5}$ DNA copy numbers $\mathrm{g}^{-1}$ soil in the CSC. The Rlv population values can be considered as baseline data, as the soil samples were taken from the CSC fields in March just prior to sowing the faba bean, and except for the field which was cropped with faba bean in both 2011 and 2015, no legumes were cropped in the fields used in the experimental rotation for at least 50 years prior to its onset. This level is consistent with the findings of Boivin et al. (2020), who recorded levels of $R l v$ nodD DNA copy number in the range of $10^{5}$ to $10^{8}$ in European agricultural soils that mostly had some previous history of faba bean cultivation, but not rhizobial inoculation. The significant, albeit relatively minor, differences between years in terms of both total $R$. leguminosarum and $R l v$ populations (e.g. comparing 2012 with 2015) may be due to the locational effects of the different fields analyzed. The higher Rlv/R. leguminosarum ratio in 2015 is intriguing in spite of overall lower values of both component populations in this year, and could be due to the prior cropping of this field with faba bean in 2011, as the recent presence of a specific legume host (e.g. pea) is known to facilitate the persistence of $R l v$ populations (Hirsch 1996; Macdonald et al. 2011).

Compared to other studies that have examined the impact of prolonged absence of legume cropping on $R l v$ populations in uninoculated northern European soils, the population densities in the present study of CSC soils with more than 50 years without legumes are relatively high. For example, Nutman and Hearne (1979) reported 1000-fold decreases in $R l v$ populations in southern English soils after 14 years under cereals and negligible levels of $R l v$ after prolonged fallow, suggesting that for maintenance of $R l v$ in soils cropping with non-legumes is preferable to no cropping at all, as these may help maintain saprophytic rhizobial populations by providing $\mathrm{C}$ e.g. from root exudates and plant decomposition (Hirsch 1996). Similar conclusions were reached by Jensen and Sørensen (1987) in their study of Danish soils 
artificially inoculated with Streptomycin-resistant Rlv strains i.e. the presence of a host legume (pea) markedly increased the survival of the inoculated strains.

The diversity of $R l v$ strains nodulating faba bean at the CSC suggests that they came from various local sources

Several rhizobium strains were isolated from the CSC and from the other sites in which BNF by faba bean and pea was estimated, as well as from other related crop and wild legumes in which BNF was not estimated. Based upon sequences of their nodAD genes, they were distributed into two distinct genotypes of Rlv; Group I which contained isolates from wild legumes and some $V$. faba CSC isolates, and Group II which contained the laboratory strain Rlv 3841 (Young et al. 2006) and most of the $V$. faba CSC isolates. Similar data were obtained by Laguerre et al. (2003), Mutch and Young (2004) and Tian et al. (2010), and the Group II from the present study is essentially an expansion of the NodDF-2 group from Mutch and Young (2004), and is equivalent to Group B1 of Boivin et al. (2020). The NodDF-2 group was considered by Mutch and Young (2004) to be a $V$. faba-specific group as strains within it could readily nodulate faba bean, but those from the other nodDF groups had a much reduced capacity to nodulate this domesticated host. In contrast to V. faba which appears to be quite selective in terms of which $R l v$ strains can nodulate it (Mutch and Young 2004), all the isolates in the present study, regardless of their original host, were shown to be capable of nodulating pea, and many performed better than a commercially used strain (rcr1045) on both the pea varieties tested. A nodulation test on faba bean using a sub-set of 14 strains from both nodAD Groups I and II (including some from the CSC) indicated that they could all nodulate this host. However, the highest-performing strains were not the same as those with pea, and there was no specific nodAD genotype associated with a high performance on either host in single inoculation tests, which agrees with Boivin et al. (2020) who concluded that $R l v$ nod genotype is unrelated to symbiotic effectiveness.

Taken together, these tests demonstrated that in spite of reports that prolonged absence of legume cropping can result in a loss of $R l v$ diversity (Depret et al. 2004) the CSC soils harboured a high diversity of effective $R l v$ capable of nodulating faba bean and pea. The maintenance of these relatively high and quite diverse $R l v$ populations may be the result of various factors including their persistence in the soil as saprophytes from legume-cropping prior to 1970 (although no record exists for the CSC sites, this cannot be excluded), but also legume weeds, including Vicia species, which were widespread in arable systems throughout the 20th century(Squire 2017), and invasion from adjacent sites (Hirsch 1996). In the case of the CSC, neighbouring farms were clearly a potential source as strains JHI981, JHI982 and JHI984 (from Carmichael and James Hutton Institute Farms) were included in the nodAD Group II that contained most of the CSC faba bean strains, as were pea strains isolated from fields neighbouring the CSC at Balruddery Farm. On the other hand, nodAD Group I was the more diverse group (in terms of host), and contained all the strains from wild Lathyrus and Vicia species resident in the field margins, and probably within the in-field seedbank during the 20th century, so we cannot necessarily conclude that the nodAD Group I made a lesser contribution to the in-field $V$. faba symbionts in the CSC. Indeed, it also harboured $V$. faba symbionts, such as another strain from Carmichael Farm (JHI983), as well as a group of 17 CSC strains that were almost exclusively isolated from faba bean cropped in 2013; these 17 strains indicate that location can also be an important determinant of which $R l v$ genotypes predominate in any given field.

\section{Conclusions}

Faba bean and pea have been grown in northern Europe for millennia, and although it has long been considered that they do not require any $\mathrm{N}$-fertiliser (http://www.pgro.org/ ; Iannetta et al. 2016; Squire et al. 2019), here we present the first comprehensive evidence that they can fix all their $\mathrm{N}$ needs, but also that in addition to these legumes having no requirement for fertiliser $\mathrm{N}$ they may also leave a residue of 50-110 kg N ha-1 $\mathrm{yr}^{-1}$ in the soil after they are harvested. With appropriate management this residual $\mathrm{N}$ can be made available to the following (non-legume) crops (Jensen et al. 2010). Based on the data from 2014 to 2015 in the present study, changes in management that could be considered to increase $\mathrm{BNF}, \mathrm{N}$-accumulation and residual $\mathrm{N}$ deposition by faba bean are to introduce a range of integrated soil 
cultivation and organic amendments, especially if particular varieties (e.g. Babylon and Boxer) shown to respond positively to this soil amendment are to be sown. Although concern has been raised that low $R l v$ populations with reduced diversity might limit faba bean BNF and yields (Sorwli and Mytton 1986), especially if the decline in pulse cropping in northern Europe is to be reversed (Iannetta et al. 2016; Squire et al. 2019), the present study suggests that as long as legume cropping has continued in some neighbouring fields, and/or if the field margins and in-field seedbank contain wild Vicia and Lathyrus species, then there will most likely be sufficient rhizobia of appropriate genotypes in most soils to support nodulation of faba bean and pea in suitable cropping areas. Nevertheless, it is also clear that not all rhizobial strains are equal, i.e. there may be potential to apply "elite" strains as inoculants for boosting BNF and grain yield, particularly on soils that have been under long periods of fallow (Nutman and Hearne 1979), and in which low Rlv populations have been estimated e.g. using the qPCR method (Macdonald et al. 2011; this study). These elite strains, however, would need to be "tailored" to a particular pulse, as strains that are highly effective on pea are not necessarily as effective on faba bean (and vice versa), and moreover, they would need to be assessed for their ability to compete in the soil for nodulation of their target hosts (Boivin et al. 2020; Mendoza-Suárez et al. 2020). On the other hand, if elite strains can compete for nodulation, Westhoek et al. (2021) have recently demonstrated that there is good reason to believe that they can then dominate as symbionts via the host plant "conditionally sanctioning" nodules occupied by other, lesser-performing strains.

It is now increasingly clear that there is a critical need to reduce inputs of fertilizer $\mathrm{N}$ into agroecosystems, particularly in the developed world, and that BNF by legumes can play a crucial role in this reduction (Udvardi et al. 2021). The unique aspects of the present study are its field scale plus the multiple years in which it was conducted, whereby it has demonstrated the enormous amounts of $\mathrm{N}$ that legume crops can fix. Given this knowledge, the proper harnessing of BNF by legumes should now be implemented to help grow arable crops more sustainably, but also to meet commitments to reducing GHG emissions.
Acknowledgements The James Hutton Institute is supported by the Rural \& Environment Science \& Analytical Services (RESAS), a division of the Scottish Government. This work was also supported by the EU-FP7 project Legume Futures and the EU H2020 projects: 'Transition paths to sUstainable legume based systems in Europe', (TRUE, Grant Agreement Number 727973); 'Designing InnoVative plant teams for Ecosystem Resilience and agricultural Sustainability' (DIVERSify, Grant Agreement Number 727824); and, 'A novel and integrated approach to increase multiple and combined stress tolerance in plants using tomato as a model', (TOMRES, Grant Agreement Number 727929). PPMI and EKJ have also been supported by the Genomia Fund (www.genomia.org.uk). MM and EKJ were partly supported by the BBSRC-Newton fund. We thank Roger Vickers at the Processors and Growers Research Organisation (PGRO) and all the growers who allowed us to sample from their fields. Colin Alexander and BIOSS are thanked for their assistance with statistical analyses. Sarah Doherty, Kirstin Buchholz, Gill Banks, Alexandre Baraúna, Linda Ford, Jak Iannetta-Mackay, Paul Neave and Linda Nell are thanked for their technical assistance, and Murray Unkovich for helpful discussions.

\section{Declarations}

Conflict of interest The authors declare no conflicts of interest.

Open Access This article is licensed under a Creative Commons Attribution 4.0 International License, which permits use, sharing, adaptation, distribution and reproduction in any medium or format, as long as you give appropriate credit to the original author(s) and the source, provide a link to the Creative Commons licence, and indicate if changes were made. The images or other third party material in this article are included in the article's Creative Commons licence, unless indicated otherwise in a credit line to the material. If material is not included in the article's Creative Commons licence and your intended use is not permitted by statutory regulation or exceeds the permitted use, you will need to obtain permission directly from the copyright holder. To view a copy of this licence, visit http://creativecommons.org/licenses/by/4.0/.

\section{References}

Altschul SF, Madden TL, Schäffer AA, Zhang J, Zhang Z, Miller W, Lipman DJ (1997) Gapped BLAST and PSIBLAST: a new generation of protein database search programs. Nucleic Acids Res 25:3389-3402

Alves BJR, Boddey RM, Urquiaga S (2003) The success of BNF in soybean in Brazil. Plant Soil 252:1-9

Ampomah OY, Huss-Danell K (2017) Genetic diversity of rhizobia nodulating native Vicia spp. in Sweden. Syst Appl Microbiol 39:203-210. https://doi.org/10.1016/j. syapm.2016.02.002

Beringer JE (1974) R factor transfer in Rhizobium leguminosarum. Microbiology 84:188-198. https://doi.org/10. 1099/00221287-84-1-188

Boivin S, Ait Lahmidi N, Sherlock D, Bonhomme M, Dijon D, Heulin-Gotty K, Le-Queré A, Pervent M, Tauzin M, Carlsson G, Jensen E, Journet E-P, Lopez-Bellido 
RJ, Seidenglanz M, Marinkovic J, Colella S, Brunel B, Young P, Lepetit M (2020) Host-specific competitiveness to form nodules in Rhizobium leguminosarum symbiovar viciae. New Phytol 226:555-568. https://doi.org/ 10.1111/nph.16392

Burchill W, James EK, Li D, Lanigan GJ, Williams M, Iannetta PPM, Humphreys J (2014) Comparisons of biological nitrogen fixation in association with white clover (Trifolium repens L.) under four fertiliser nitrogen inputs as measured using two $15 \mathrm{~N}$ techniques. Plant Soil 385:287-302. https://doi.org/10.1007/ s11104-014-2199-1

Carlsson G, Huss-Danell K (2003) Nitrogen fixation in perennial forage legumes in the field. Plant Soil 253:353-372

Carlsson G, Huss-Danell K (2014) Does nitrogen transfer between plants confound $15 \mathrm{~N}$-based quantifications of N2 fixation? Plant Soil 374:345-358. https://doi.org/10. 1007/s11104-013-1802-1

Cleveland CC, Townsend AR, Schimel DS, Fisher H, Howarth R, Hedin LO, Perakis SS, LE F, Von Fischer JC, Elseroad A, Wasson MF (1999) Global patterns of terrestrial biological nitrogen $\left(\mathrm{N}_{2}\right)$ fixation in natural ecosystems. Glob Biogeochem Cycles 13:623-645

Daniell TJ, Davidson J, Alexander CJ, Caul S, Roberts DM (2012) Improved real-time PCR estimation of gene copy number in soil extracts using an artificial reference. $\mathrm{J}$ Microbiol Methods 91:38-44. https://doi.org/10.1016/j. mimet.2012.07.010

De Meyer SE, Van Hoorde K, Vekeman B, Braeckman T, Willems A (2011) Genetic diversity of rhizobia associated with indigenous legumes in different regions of Flanders (Belgium). Soil Biol Biochem 43:2384-2396. https://doi.org/10.1016/j.soilbio.2011.08.005

Denton MD, Pearce DJ, Peoples MB (2013) Nitrogen contributions from faba bean (Vicia faba L.) reliant on soil rhizobia or inoculation. Plant Soil 365:363-374. https:// doi.org/10.1007/s11104-012-1393-2

Depret G, Houot S, Allard M-R, Breuil M-C, Nouaim R, Laguerre G (2004) Long-term effects of crop management on Rhizobium leguminosarum biovar viciae populations. FEMS Microbiol Ecol 51:87-97. https://doi.org/ 10.1016/j.femsec.2004.07.009

Fred EB, Waksman SA (1928) Laboratory manual of general microbiology. McGraw-Hill, New York

Freitag S, Verrall SR, Pont SDA, McRae D, Sungurtas JA, Palau R, Hawes C, Alexander CJ, Allwood JW, Foito A, Stewart D, Shepherd LVT (2018) Impact of conventional and integrated management systems on the watersoluble vitamin content in potatoes, field beans and cereals. J Agric Food Chem 66:831-841

Giambalvo D, Ruisi P, Saia S, Di Miceli G, Frenda AS, Amato G (2012) Faba bean grain yield, N2 fixation, and weed infestation in a long-term tillage experiment under rainfed Mediterranean conditions. Plant Soil 360:215-227. https://doi.org/10.1007/ s11104-012-1224-5

Guinet M, Nicolardot B, Revellin C, Durey V, Carlsson G, Voisin A-S (2018) Comparative effect of inorganic N on plant growth and N2 fixation of ten legume crops: towards a better understanding of the differential response among species. Plant Soil 432:207-227. https://doi.org/10.1007/s11104-018-3788-1

Gyaneshwar P, Hirsch AM, Moulin L, Chen WM, Elliott GN, Bontemps C, Estrada-de Los Santos P, Gross E, Dos Reis FB, Sprent JI, Young JP, James EK (2011) Legumenodulating betaproteobacteria: diversity, host range, and future prospects. Mol Plant-Microbe Interact 24:12761288. https://doi.org/10.1094/MPMI-06-11-0172

Hall TA (1999) BIOEDIT: A user-friendly biological sequence alignment editor and analysis program for Windows 95/98/ NT. Nucleic Acids Symp Ser 41:95-98

Hauggaard-Nielsen H, Holdensen L, Wulfsohn D, Jensen ES (2010) Spatial variation of N2-fixation in field pea (Pisum sativum L.) at the field scale determined by the $15 \mathrm{~N}$ natural abundance method. Plant Soil 327:167184. https://doi.org/10.1007/s11104-009-0043-9

Hawes C, Alexander CJ, Begg GS, Iannetta PPM, Karley AJ, Squire GR, Young M (2018) Plant responses to an integrated cropping system designed to maintain yield whilst enhancing soil properties and biodiversity. Agronomy 8:229

Hirsch PR (1996) Population dynamics of indigenous and genetically modified rhizobia in the field. New Phytol 133:159-171

Hossain Z, Wang X, Hamel C, Knight JD, Morrison MJ, Gan $\mathrm{Y}$ (2016) Biological nitrogen fixation by pulse crops on the semiarid Canadian Prairie. Can J Plant Sci. https:// doi.org/10.1139/cjps-2016-0185

Hothorn T, Bretz F, Westfall P (2008) Simultaneous inference in general parametric models. Biom J 50:346-363

Iannetta PP, Young M, Bachinger J, Bergkvist G, Doltra J, Lopez-Bellido RJ, Monti M, Pappa VA, Reckling M, Topp CF, Walker RL, Rees RM, Watson CA, James EK, Squire GR, Begg GS (2016) A comparative nitrogen balance and productivity analysis of legume and nonlegume supported cropping systems: The potential role of biological nitrogen fixation. Front Plant Sci 7:1700. https://doi.org/10.3389/fpls.2016.01700

Jensen ES (1986) Symbiotic N2 fixation in pea and field bean estimated by $15 \mathrm{~N}$ fertilizer dilution in field experiments with barley as a reference crop. Plant Soil 92:3-13. https://doi.org/10.1007/bf02372260

Jensen ES, Peoples MB, Boddey RM, Gresshoff PM, Hauggaard-Nielsen H, Alves BJR, Morrison MJ (2012) Legumes for mitigation of climate change and the provision of feedstock for biofuels and biorefineries. A review. Agron Sustain Dev 32:329-364. https://doi.org/10.1007/ s13593-011-0056-7

Jensen ES, Peoples MB, Hauggaard-Nielsen H (2010) Faba bean in cropping systems. Field Crops Res 115:203-216. https://doi.org/10.1016/j.fcr.2009.10.008

Jensen ES, Sørensen LH (1987) Survival of Rhizobium leguminosarum in soil after addition as inoculant. FEMS Microbiol Ecol 3:221-226. https://doi.org/10.1111/j.1574-6968. 1987.tb02359.x

Kumar S, Stecher G, Li M, Knyaz C, Tamura K (2018) MEGA $\mathrm{X}$ : Molecular evolutionary genetics analysis across computing platforms. Mol Biol Evol 35:1547-1549. https:// doi.org/10.1093/molbev/msy096

Laguerre G, Louvrier P, Allard M-R, Amarger N (2003) Compatibility of rhizobial genotypes within natural 
populations of Rhizobium leguminosarum biovar viciae for nodulation of host legumes. Appl Environ Microbiol 69:2276-2283. https://doi.org/10.1128/aem.69.4.22762283.2003

Liu L, Knight J, Lemke RL, Farrell RE (2019) A side-by-side comparison of biological nitrogen fixation and yield of four legume crops. Plant Soil 442:169-182. https://doi. org/10.1007/s11104-019-04167-x

López-Bellido L, López-Bellido RJ, Redondo R, Benítez J (2006) Faba bean nitrogen fixation in a wheat-based rotation under rainfed Mediterranean conditions: Effect of tillage system. Field Crops Res 98:253-260. https://doi.org/ 10.1016/j.fcr.2006.03.001

Macdonald CA, Clark IM, Hirsch PR, Zhao F-J, McGrath SP (2011) Development of a real-time PCR Assay for detection and quantification of Rhizobium leguminosarum bacteria and discrimination between different biovars in zinc-contaminated soil. Appl Environ Microbiol 77:46264633. https://doi.org/10.1128/aem.02232-10

Mendoza-Suárez MA, Geddes BA, Sánchez-Cañizares C, Ramírez-González RH, Kirchhelle C, Jorrin B, Poole PS (2020) Optimizing Rhizobium-legume symbioses by simultaneous measurement of rhizobial competitiveness and $\mathrm{N}_{2}$ fixation in nodules. Proc Natl Acad Sci 117:98229831. https://doi.org/10.1073/pnas.1921225117

Mutch LA, Young JPW (2004) Diversity and specificity of Rhizobium leguminosarum biovar viciae on wild and cultivated legumes. Mol Ecol 13:2435-2444

Nutman PS, Hearne R (1979) Persistence of nodule bacteria in soil under longterm cereal cultivation. Rothamsted Experimental Station Report for 1979, Part 2

Peix A, Ramírez-Bahena MH, Velázquez E, Bedmar EJ (2015) Bacterial associations with legumes. CRC Crit Rev Plant Sci 34:17-42. https://doi.org/10.1080/07352689.2014. 897899

Peoples MB, Bowman AM, Gault RR, Herridge DF, McCallum MH, McCormick KM, Norton RM, Rochester IJ, Scammell GJ, Schwenke GD (1991) Factors regulating the contributions of fixed nitrogen by pasture and crop legumes to different farming systems of eastern Australia. Plant Soil 228:29-41

Peoples MB, Brockwell J, Herridge DF, Rochester IJ, Alves BJR, Urquiaga S, Boddey RM, Dakora FD, Bhattarai S, Maskey SL, Sampet C, Rerkasem B, Khans DF, Hauggaard-Nielsen H, Jensen ES (2009) The contributions of nitrogen-fixing crop legumes to the productivity of agricultural systems. Symbiosis 48:1-17. https://doi.org/10. 1007/BF03179980

Peoples MB, Giller KE, Jensen ES, Herridge DF (2021) Quantifying country-to-global scale nitrogen fixation for grain legumes: I. Reliance on nitrogen fixation of soybean, groundnut and pulses. Plant Soil. https://doi.org/10.1007/ s11104-021-05167-6

R core Team (2013) R: A language and environment for statistical computing. R Foundation for Statistical Computing, Vienna

R Studio Team (2015) RStudio: Integrated Development for R. RStudio. RStudio Inc., Boston

Rose TJ, Kearney LJ, Erler DV, Rose MT, Van Zwieten L, Raymond CA (2018) Influence of growth stage and seed nitrogen on $\mathrm{B}$ values and potential contributions to error in estimating biological $\mathrm{N} 2$ fixation using the $15 \mathrm{~N}$ natural abundance method. Plant Soil 425:389-399. https://doi. org/10.1007/s11104-018-3600-2

Ruijter JM, Ramakers C, Hoogaars WMH, Karlen Y, Bakker O, van den Hoff MJB, Moorman AFM (2009) Amplification efficiency: linking baseline and bias in the analysis of quantitative PCR data. Nucleic Acids Res 37:e45-e45. https://doi.org/10.1093/nar/gkp045

Sievers F, Wilm A, Dineen D, Gibson TJ, Karplus K, Li W, Lopez R, McWilliam H, Remmert M, Söding J, Thompson JD, Higgins DG (2011) Fast, scalable generation of high-quality protein multiple sequence alignments using Clustal Omega. Mol Syst Biol 7:539. https://doi.org/10. 1038/msb.2011.75

Sorwli FK, Mytton LR (1986) The nitrogen fixing potential of Vicia faba rhizobia (R. leguminosarum) from different agricultural locations. Plant Soil 92:249-254

Sprent JI, Bradford AM, Norton C (1977) Seasonal growth patterns in field beans (Vicia faba) as affected by population density, shading and its relationship with soil moisture. J Agric Sci 88:293-301. https://doi.org/10.1017/s0021 859600034791

Squire GR (2017) Defining sustainable limits during and after intensification in a maritime agricultural ecosystem. Ecosyst Health Sustain 3:1368873. https://doi.org/10.1080/ 20964129.2017.1368873

Squire GR, Quesada N, Begg GS, Iannetta PPM (2019) Transitions to greater legume inclusion in cropland: Defining opportunities and estimating benefits for the nitrogen economy. Food Energy Secur 8:e00175. https://doi.org/10. $1002 /$ fes 3.175

Tian CF, Young JP, Wang ET, Tamimi SM, Chen WX (2010) Population mixing of Rhizobium leguminosarum bv. viciae nodulating Vicia faba: the role of recombination and lateral gene transfer. FEMS Microbiol Ecol 73:563576. https://doi.org/10.1111/j.1574-6941.2010.00909.x

Udvardi M, Below FE, Castellano MJ, Eagle AJ, Giller KE, Ladha JK, Liu X, McClellan Maaz T, Nova-Franco B, Raghuram N, Robertson GP, Roy S, Saha M, Schmidt S, Tegeder M, York LM, Peters JW (2021) A research road map for responsible use of agricultural nitrogen. Front Sustain Food Syst 5. https://doi.org/10.3389/fsufs.2021. 660155

Unkovich MJ, Baldock J, Peoples MB (2010) Prospects and problems of simple linear models for estimating symbiotic N2 fixation by crop and pasture legumes. Plant Soil 329:75-89. https://doi.org/10.1007/ s11104-009-0136-5

Unkovich MJ, Herridge DF, Peoples MB, Cadisch G, Boddey RM, Giller KE, Alves BJR, Chalk PM (2008) Measuring plant-associated nitrogen fixation in agricultural systems. ACIAR, Canberra

Van Zwieten L, Rose T, Herridge DF, Kimber S, Rust J, Cowie A, Morris S (2015) Enhanced biological N2 fixation and yield of faba bean (Vicia faba L.) in an acid soil following biochar addition: dissection of causal mechanisms. Plant Soil 395:7-20. https://doi.org/10.1007/ s11104-015-2427-3

Vincent JM (1970) A manual for the practical study of the root-nodule bacteria. International Biological Programme by Blackwell Scientific, Oxford 
Voisin AS, Munier-Jolain NG, Salon C (2010) The nodulation process is tightly adjusted to plant growth. An analysis using environmentally and genetically induced variation of nodule number and biomass in pea. Plant Soil 337:399412. https://doi.org/10.1007/s11104-010-0536-6

Walker RL, Watson CA (2011) Are inadequate soil populations of complimentary rhizobia restricting UK self sufficiency in legume protein? Aspects of Applied Biology: Agricultural Ecology Research: Its role in delivering sustainable farm systems, Dundee

Westhoek A, Clark LJ, Culbert M, Dalchau N, Griffiths M, Jorrin B, Karunakaran R, Ledermann R, Tkacz A, Webb I, James EK, Poole PS, Turnbull LA (2021) Conditional sanctioning in a legume-Rhizobium mutualism. Proc Natl Acad Sci 118:e2025760118. https://doi.org/10.1073/pnas. 2025760118
Wickham H (2016) ggplot2: elegant graphics for data analysis. Springer-Verlag, New York

Wickham H, François R, Henry L, Müller K (2019) dplyr: A grammar of data manipulation. https://cran.rproject.org/ package $=$ dplyr

Young JPW, Crossman LC, Johnston AWB, Thomson NR, Ghazoui ZF, Hull KH, Wexler M, Curson ARJ, Todd JD, Poole PS (2006) The genome of Rhizobium leguminosarum has recognizable core and accessory components. Genome Biol 7:R34

Publisher's note Springer Nature remains neutral with regard to jurisdictional claims in published maps and institutional affiliations. 